\title{
A extensão da impostura
}

\author{
The extent of imposture
}

Ana Maria C. Aleksandrowicz 1

1 Departamento de Ciências Sociais, Escola Nacional de Saúde Pública. Fundação Oswaldo Cruz. Rua Leopoldo Bulhões 1480 , 9 o andar, Rio de Janeiro, RJ 21041-210, Brasil. analeks@unisys.com.br

\begin{abstract}
This paper comments on Sokal and Bricmont's stance towards interdisciplinarity approaches between the human and natural sciences, as stated in their controversial book Impostures Intellectuelles (Fashionable Nonsense) (1999). It happens that interdisciplinarity is a subject of major importance to "new paradigms" in Public Health. First, the paper identifies different types of interaction between these "two cultures", such as transdisciplinary trends and the "Science Wars", and emphasizes their unproductive aspects. Second, it proposes a revaluation of pragmatism as a suitable way of including philosophical considerations in interdisciplinary Public Health research, exemplified by a correlation between the ideas of Henri Atlan (1991) and notions of risk theory (or model).
\end{abstract}

Key words Philosophy; Human Sciencies; Natural Sciences

Resumo A partir da crítica ao livro Imposturas Intelectuais (1999), de A. Sokal \& J. Bricmont, enfoca-se o tema da interdisciplinaridade entre Ciências Humanas e Ciências Naturais, no que esta abordagem é imprescindivel aos assim chamados "novos paradigmas" de Saúde Pública, sob dois aspectos: (a) distinguir as diversas possibilidades de interação entre as "Duas Culturas", dentre as quais ressaltam-se as ditas Transdisciplinaridades (incluindo-se aí as Teorias da Complexidade) e a usual demarcação acadêmica de fronteiras associada às Guerras das Ciências, assinalando-se os aspectos restritivos à melhor operacionalização do pensamento em cada uma destas vertentes; (b) revalorizar a dimensão pragmática de determinado enfoque filosófico quanto a questões de Fundamentos na pesquisa teórica em Saúde Pública, aqui exemplificado em termos de uma revisão aos conceitos de "possível" e "potencial" (Atlan, 1991) no modelo de risco.

Palavras-chave Filosofia; Ciências Humanas; Ciências Naturais 
"Interpretar as interpretações dá mais trabalho do que interpretar a própria coisa, mas escrevemos mais livros sobre os livros do que sobre os próprios assuntos mesmos; comentamo-nos uns aos outros. Há excesso de comentadores, mas escassez de autores. A principal ciência do século consiste em entender os sábios; não está nisto o fim último de nossos estudos? Nossas opiniões sustentam-se mutuamente, uma serve de degrau à outra, e assim acontece que quem sobe mais alto e maior reputação adquire não tem em verdade grande mérito, pois não faz senão superar de um átimo o que vem logo abaixo" (Montaigne, 1972:483) (...) "um dos meus amigos, a lidar com um indivíduo desta espécie, se pôs, por passatempo, a recitar-lhe, em uma trapalhada de frases, citações sem nexo, embora entremeadas de palavras relativas ao problema; e assim se divertiu o dia inteiro com o tolo que tomara a coisa a sério e dava tratos às bolas para responder às objeções. No entanto, tal indivíduo era homem de letras, gozava de certa reputação e de boa posição social. (...) Quem olhar de perto esta espécie de gente, por toda parte encontradiça, achará como eu que, as mais das vezes, ela própria não se entende, como não entende os outros" (Montaigne, 1972:76).

\section{O que são as "Imposturas Intelectuais"}

Em 1996, uma revista cultural americana, a Social Text, publicou - em edição especial, destinada a refutar a crítica dirigida ao pós-modernismo e ao construtivismo social por cientistas renomados - um artigo intitulado Transgressing the boundaries: Toward a transformative hermeneutics of quantum gravity, de autoria de um físico da Universidade de Nova York, Alan Sokal (1996). Neste, Sokal propunha-se a defender uma forma extrema de relativismo cognitivo, culminando na afirmativa de que a realidade física (e não apenas nossas teorias sobre ela) é no fundo uma construção social e lingüística (Sokal, 1996). Logo após, Sokal revelou que o artigo era uma paródia, já que todos os argumentos desenvolvidos eram flagrantemente ilógicos e/ou absurdos, apenas ganhando aparência de coerência em virtude da habilidosa justaposição de citações - também desprovidas de sentido - de eminentes intelectuais franceses e americanos adeptos de extrapolações de mal digeridos conceitos da Matemática e Ciências Naturais para a Filosofia, Psicanálise e Ciências Sociais. O escândalo provocado foi assunto para matérias nas primeiras páginas de jornais importantes (como o New York Times, o Observer e o Le Monde), alcançando enorme re- percussão nos meios acadêmicos. Assim estimulado, Sokal decidiu escrever um livro em que detalhou sua posição, agora, com outro físico da Universidade de Louvain, Jean Bricmont. Publicado primeiro na França em 1997 - e lançado recentemente no Brasil (Sokal \& Bricmont, 1999) - Imposturas Intelectuais deixa atrás de si um rastro de apaixonados debates, em centenas de artigos na imprensa e na Internet.

Sokal e Bricmont não são claros no alcance e delimitações de seu propósito. Embora pretendam oferecer uma contribuição à critica "do evidentemente nebuloso 'Zeitgeist' que denominamos 'pós-modernismo'” (Sokal \& Bricmont, 1999:18), eles evitam prudentemente aprofundar o significado do termo. Neste processo, ignoram alguns aspectos cruciais desta tendência, como, por exemplo, a ênfase na informação em íntima relação com a problematização do conhecimento e a secundarização das questões ontológicas face às gnoseológicas (Valle-Barbosa, 1990). Todavia, detêm-se, em todo um capítulo, sobre a Epistemologia da ciência, margeando e/ou banalizando discussões complexas.

A Filosofia da ciência é área bastante estrita, exigindo, para a adequada apreensão de seus conceitos, um entendimento peculiar, que vá além de certo esquema impingido à história recente da matéria e de sua atual situação. Dentro de tal visão esquemática, fala-se, por exemplo, tanto em "filosofia positivista ou pós-positivista da ciência" (debate que acompanha o do relativismo), mas de forma tal que só tem em comum com os especialistas do campo o fato de estes nunca utilizarem estes termos na acepção usual simplificada (Laudan, 1990).

Entretanto, Sokal \& Bricmont confessam suas limitações nas assim chamadas Humanidades e, uma vez feitas as ressalvas necessárias, permitem-nos focar alguns aspectos de sua proposta que são de interesse para a Saúde Pública. Embora explicitem não acreditar que scholars de áreas não-científicas se vinculem sempre aos abusos que denunciam (Sokal \& Bricmont, 1999), é óbvia a dificuldade desses autores para entender e aceitar a cooperação entre as "Duas Culturas" - termo que será explicado adiante -, que, a seu ver, estão mais afastadas mentalmente que nunca (Sokal \& Bricmont, 1999). Em contraste, cada vez mais tem-se evidenciado para a Saúde Pública - assim como para outros espaços de confluências teoria-prática - quão imprescindível é o enfoque interdisciplinar, o qual, ao propiciar um conhecimento ampliado de dado universo de atuações, permite que sejam satisfeitas necessidades internas em múltiplos níveis, inclusive naqueles diretamente relacionados à reflexão e 
à formulação de novas hipóteses acerca da práxis desenvolvida (Nunes, 1994).

Para os "novos paradigmas" da Saúde Pública são atualmente viscerais os encaminhamentos propiciados a partir do debate de questões que abrangem postulações não só éticas, mas também filosóficas lato sensu. Estas situam-se no cerne mesmo das urgentíssimas redefinições necessárias de conceitos como qualidade de vida, autonomia do indivíduo, autodeterminação de grupos sociais, capacidades de escolha, decisão e exercício da vontade para operacionalizações em prevenção-promoção da Saúde (Carvalho, 1996). Muitas destas indagações encontram respaldo teórico em pesquisas de natureza essencialmente interdisciplinar quais as de auto-organização. O livro de Sokal \& Bricmont não encontrou tanta receptividade só por exacerbar firulas acadêmicas em torno do pós-modernismo. Fala de uma desconfiança que, subjacente a práticas intelectuais equivocadas, compromete inclusive a credibilidade acerca da praticidade das questões de Fundamentos - em especial, daquelas apresentadas pelos representantes das Humanidades que buscam consonância com as Ciências Naturais - para as discussões em políticas públicas, aqui incluídas as de Saúde.

Quando Sokal \& Bricmont enfatizam erros grosseiros em transposições interdisciplinares por parte de autores de Filosofia e Ciências Sociais, pretendendo ou não generalizar o alcance deste procedimento, lançam dúvidas a respeito da capacidade de eficácia de um tipo de pesquisa em Fundamentos. Neste sentido, recortamos posições críticas pertinentes no texto de Sokal \& Bricmont (1999), como: as extrapolações inadequadas de terminologias e conceitos das Ciências Exatas e Naturais para contextos das Ciências Humanas (aqui incluída a utilização tendenciosa de jargões científicos); o relativismo epistêmico/cognitivo (oriundo da filosofia e da sociologia), especificamente a idéia de que a moderna ciência não é mais que um "mito", uma "narração", uma "construção social”, entre muitos outros; a ostentação de erudição superficial por meio da manipulação de frases e sentenças - na verdade, carentes de sentido - com a finalidade de impressionar os leitores não-cientistas mediante um pretenso status de credibilidade baseado na comprovação científica.

Seria conseqüência desta atitude a "confusão intelectual” - termo utilizadíssimo por Sokal \& Bricmont - na inter-relação entre disciplinas, levando os autores das ciências humanas a saírem lesados deste embate, em virtude de sua confissão tácita de incapacidade no sen- tido de propor soluções com consistência teórica e/ou objetividade operacional para os dilemas que esmiuçam.

Em intermezzos entre os capítulos nos quais assinalam tais falhas em obras de Lacan, Kristeva, Iriday, Latour, Baudrillard, Deleuze, Guattari e Virilio, dentre outros, Sokal \& Bricmont vão delineando suas próprias sugestões de compreensão ao panorama que consideram de imposturas generalizadas; no Epílogo, assinalam seus três principais efeitos negativos: desperdício de tempo nas Ciências Humanas, favorecimento ao obscurantismo e enfraquecimento político (da esquerda) (Sokal \& Bricmont, 1999), citando, a propósito, exemplos bem escolhidos de infrutíferas discussões pseudo-pósmodernistas em palestras a respeito de assuntos internacionais e de questões estratégicas em países pobres (Sokal \& Bricmont, 1999).

Estes trechos receberam ressalvas particularmente mordazes (Sturrock, 1998; Mellor, 1999), tendo sido considerados (adequadamente) pouco consistentes e desatualizados. Mas, como é comum neste tipo de confronto, nada foi contraposto por parte dos contestadores das Ciências Humanas, sem dúvida melhor gabaritados para análises destes temas, o que lhes enfraquece a réplica e sustenta a argumentação de Sokal.

O desmascaramento pretendido por Sokal \& Bricmont não é importante pelos alvos que escolhem ou pelo cunho sensacionalista de que possa ou não estar investido, mas sim por desafiar-nos a uma resposta significativa, patenteando inadequações em um movimento irreversível da Cultura, como o da pesquisa interdisciplinar. Aqui procuraremos formulá-la, destacando, como eixos para discussão, a situação atual de lutas e alianças entre disciplinas pelo Poder Intelectual e a necessária recuperação da dimensão pragmática no discurso das $\mathrm{Hu}$ manidades - suas especificidades preservadas - em sintonia (e não mescla inoperante) com o discurso científico.

\section{As Duas Culturas, as transdisciplinaridades e as Guerras das Ciências}

O termo "Duas Culturas" foi consagrado a partir de sua utilização na famosa conferência "As Duas Culturas e a Revolução Científica”, de 1963, em que o físico e romancista C. P. Snow compara a freqüente ignorância das pessoas cultas (referindo-se aqui à acepção tradicional de cultura, ou seja, em Ciências Humanas) acerca de conhecimentos básicos em Ciências Na- 
turais. Snow (1993) relata o quão natural lhes parecia ignorar a Segunda Lei da Termodinâmica, assinalando, entretanto, que esta seria o equivalente científico, por exemplo, à leitura de uma obra de Shakespeare. O episódio é citado por Sokal \& Bricmont (1999), os quais acrescentam que a interdisciplinaridade, atualmente em voga, parece-lhes proveitosa para as diversas áreas de pensamento envolvidas; portanto, em aparente contradição com outras afirmações suas a respeito (Sokal \& Bricmont, 1999). O equívoco se esclarece quando Sokal \& Bricmont estabelecem as regras para tal parceria frutífera, das quais a mais importante, quando esta iniciativa parte das Ciências Humanas (conforme a tônica do livro), seria o estudo adequado das teorias científicas relevantes, a serem comparadas com hipóteses das Ciências Humanas em nível profundo o bastante para escapar ao plano insuficiente da vulgarização (Sokal \& Bricmont, 1999). Por mais que os autores tentem evitar, não se pode deixar de sentir um certo "didatismo" das Ciências Naturais no que se refere aos procedimentos interdisciplinares a serem adotados pelas Ciências Humanas, sem preocupação equivalente daquelas em relação a estas.

Neste mesmo trecho criticam o termo "Guerra das Ciências", que lhes parece infeliz e diretamente relacionado ao fato de que "pesquisadores no campo das ciências sociais podem legitimamente se sentir ameaçados pela idéia de que a neurofisiologia e a sociobiologia irão substituir suas disciplinas" (Sokal \& Bricmont, 1999:203). Tentando estabelecer um paralelismo com as "ameaças" por parte das Humanidades que poderiam afetar a Ciência, citam, a seguir, a astrologia como ensaiando estar em "pé de igualdade" com a Astronomia. A ser levada a sério esta afirmação, Sokal \& Bricmont atestam absoluta ignorância em termos do que são as Ciências Humanas, ao menos em termos acadêmicos tradicionais, parecendo evidenciar uma inversão completa da situação conforme apresentada por Snow em relação às Duas Culturas.

A atitude de Sokal \& Bricmont nos é útil por ser paradigmática de uma diferença marcante - na qual nos deteremos - quanto ao entendimento das relações interdisciplinares, conforme estas sejam apresentadas por cientistas ou pesquisadores das áreas humanas em termos de sua própria constituição enquanto alianças ou embates.

Entre os cientistas - a partir, naturalmente, de certo nível de envolvimento em pesquisas de Fundamentos -, sempre foi bastante freqüente o interesse e o respeito face à possibili- dade de diálogo com as Humanidades, mesmo porque se tratava de pessoas cultas lato sensu. Heisenberg (1990), por exemplo, hesitou longamente entre a música e a física, sendo bem dotado para ambas. Pode-se mesmo falar de uma tradição de tentativas de aproximar as descobertas em Física - em particular, desde a Mecânica Quântica - de um seu aproveitamento indireto nos campos do social. Cientistas definiam-se politicamente, na época das duas grandes guerras, tornando públicas as prováveis conseqüências catastróficas oriundas do mau uso da energia nuclear. Propugnavam pela cooperação entre os conhecimentos oriundos da Filosofia natural, da Ética, Sociologia e Antropologia, que, conjugados, levariam à superação de preconceitos culturais por via do reconhecimento de uma riqueza intrínseca à realidade (meta)física, compartilhada por todos os povos, que se sobreporia a qualquer barreira mental discriminatória (Bohr, 1995). Isto porque “(...) a ciência, que não conhece fronteiras nacionais e cujas realizações são um patrimônio comum da humanidade, tem unido os homens, em todas as eras (...)" (Bohr, 1995:105). Ao que Heisenberg acrescenta: "A física moderna (...) faz nascer a esperança de que, no estado final de unificação, numerosas tradições culturais possam viver lado a lado e combinar diferentes atividades humanas numa nova espécie de equilíbrio entre o pensamento e a ação, entre a atuação e a meditação" (Heisenberg, 1990:71).

Ingênuas que pareçam estas intenções, alcunháveis de canhestras em sua formulação filosófica ou política, elas marcam um estilo que se tem mantido inalterado - e prestigiado - ao longo do século. A Física mantém-se fiel a uma nunca abandonada parceria com a Filosofia. A natureza redescoberta enquanto physis auxilia a compreender a complexidade das questões com as quais se confrontam as ciências da sociedade na "nova aliança" re-afirmada desde sempre e re-interpretada por Prigogine \& Stengers (1991). Embora este termo - tão em voga em determinado momento (veja-se o título da obra seminal de Newton, Princípios Matemáticos da Filosofia Natural com 1a edição em 1687) - tenha caído em desuso, físicos propõem sistematicamente uma nova Filosofia da Natureza harmonizada com as consideráveis realizações da ciência moderna (Nicolescu, 1983). Quando se pronunciam, fazem-no em tom de confiança absoluta, na medida em que a Física se instrumentaliza, junto às Matemáticas, na esfera das Essências Perenes. Omnés, também físico, em Filosofia da Ciência Contemporânea (1995), declara que "os princípios da ciência estarão um dia tão próximos do coração e das en- 
tranhas das coisas que se tornará possível remodelar por eles a filosofia" (Omnés, 1995:9), fazendo assim "soar o contínuo de um canto de esperança” (Omnés, 1995:299).

Seguindo o deslocamento da Física para a Biologia como eixo do saber científico predominante que assegura realidades, Eccles (neurocientista) justapõe suas idéias às de Popper em cooperação interdisciplinar, na qual, respeitadas certas diferenças de enfoque, defendem a mesma tese de interação psicofísica (Popper \& Ecles, 1995). De Duve (1998), bioquímico, mantém a tônica otimista. Acompanhando o desenvolver da vida na Terra - para ele, segundo imperativo cósmico -, dá ao universo um sentido, o de "refletir sobre si mesmo, descobrir a própria estrutura e apreender entidades imanentes como a verdade, a beleza, o bem e o amor" (De Duve, 1998:394).

É, em geral, sob a égide conjunta dessas disciplinas - Física, Filosofia e algumas vertentes da Biologia - que se processam os chamados movimentos transdisciplinares, orientação paralela à interdisciplinar que, ao diálogo entre as duas culturas, pretende aliar uma dimensão específica de sua universalidade e uma assumida vocação ética (Random, 1996). Embora se procure aqui uma valoração eqüitativa de todos os saberes, em razão desta mesma qualidade democrática, a transdisciplinaridade tende à ampla aceitação de teorias ainda em fase experimental ou altamente questionáveis segundo os padrões convencionais - como o neo-vitalismo -, o que dificulta sua inserção nos quadros acadêmicos.

O mesmo tipo de indefinição arranha os objetivos e o embasamento epistemológico da Complexidade (também uma aliança do tipo transdisciplinar), que seria, antes de tudo, um "modo complexo de pensar (que) propor-se-ia a ultrapassar a visão disjuntiva pertinente às ciências tal como estão tradicionalmente constituídas" (Castiel, 1994:33). A idéia de complexidade teria reaparecido marginalmente a partir da cibernética e da teoria da informação, que teriam retomado a intuição, neste sentido, de Bachelard (Morin, 1996). Daí, seu campo de abrangência passou a incluir praticamente todas as disciplinas (inclusive as vertentes reflexivas de Economia e Direito), pois, na medida em que a complexidade se torna o conceito central, os discursos científicos, antropológicos e artísticos podem articular infinitas relações complexas (Deschamps, 1991).

As alianças transdisciplinares não oferecem ameaça dado seu limitado espectro de atuação e sua não interferência em áreas de prestígio que possam implicar investimentos de recur- sos e direcionamento de pesquisas. Tendo, conforme foi descrito, sua sustentação teórica nas Ciências - não obstante professarem intenções generosas de contribuições ao social/político fazem-no apenas em termos educativos lato sensu. Retiram-se assim da Guerra das Ciências, não sendo de admirar que Sokal \& Bricmont tenham deixado de fazer referência a quaisquer de seus expoentes em Imposturas Intelectuais.

Esta contenda mantém-se acesa onde se procura preservar maior especificidade - donde, a princípio, condição de intervenção efetiva na realidade - entre os saberes. Os especialistas que Sokal \& Bricmont citam filiam-se a propósitos renovadores dentro de suas próprias disciplinas: Lacan, na Psicanálise; Latour, na Sociologia da Ciência; Baudrillard, na Semiologia etc. Não encampam projetos transdisciplinares. Não se propõem o trabalho de equipe - obrigatório nessas vertentes - que, ao sujeitar-se à imprecisão do alcance, resguardase do erro grosseiro. Em lugar disso, utilizam abusivamente termos e linhas de raciocínio das áreas científicas como se o fizessem. Esquecem-se do postulado fundamental da interdisciplinaridade que dispõe que “(...) o novo espírito epistemológico incita à multiplicação dos olhares científicos e ao seu controle cruzado" (Araújo-Jorge, 1994:290). Com esta atitude utilizando ou não um pretenso "relativismo epistêmico/cognitivo" para se justificar - deixam a nítida impressão de (ab)uso do inegável prestígio atual do discurso científico, permitindo a inferência de seu próprio descrédito em relação à condição de repercussão semelhante de um discurso específico das Humanidades.

A "Guerra das Ciências" - ou seja, pela autoridade entre os saberes científico e das $\mathrm{Hu}$ manidades -, da qual o texto de Sokal \& Bricmont seria mais uma escaramuça (Fujimura, 1998; Mellor, 1999), pode ser remontada a estas mesmas Humanidades, desde as eternas dissensões franceses-ingleses, às quais, mais adequadamente, as diatribes de Sokal e Bricmont são aplicáveis. O discurso das Ciências sempre primou pelo cunho universalista. Ao invés, desde a definição dos próprios termos "cultura" e “civilização", franceses, ingleses e alemães discordam em termos de auto-imagens nacionais (Elias, 1990). E mantêm um cetro de soberania entre si enquanto nesta disputa, já que não lhes interessa a contribuição das nações fora de suas periferias de influência (Toynbee, 1981). Ao encamparmos uma veemência "pró" ou “contra” Sokal \& Bricmont versus franceses, ao renunciarmos a um caráter nosso da apreciação eqüidistante, oriunda do simples fato de 
sermos outra cultura, identificamo-nos com o jogo desta supremacia. E com os estertores de suas recentes manifestações de fazer face, por si só, aos desafios propostos às Humanidades neste final de século.

Entregues a si mesmas, as Humanidades mais não têm feito que constatar uma falência progressiva de valores e possibilidades de atuação. Ao mesmo tempo que exigem a exclusividade de análise no que diga respeito à intervenção no social, detêm-se no clima da década de 80, quando Lasch (1986) já aponta para uma "mentalidade de sobrevivência", em que, face às condições sempre mais árduas de contato com a realidade, prefere-se uma "apatia apocalíptica” (já que a crise da sociedade do século XX não apresenta solução coletiva ou política). Castoriadis, em 1996, acentua esta "escalada da insignificância”, caracterizada por um "conformismo generalizado". Em artigos recentes, Kurz $(1997,1998,1999)$ resume a situação em uma série de locuções adjetivas, subordinando substantivos imponentes a conceitos que a estes deveriam ser acessórios ( $A$ Expropriação do Tempo; A Expansão do Caos; A Estetização da Crise). Lúcido e pertinente, este tipo de discurso pouco tem a oferecer ao indivíduo/grupo social padrão, senão uma desesperançada e dúbia "conscientização" - pois por via racional exclusiva -, donde poder dar-se ao luxo de redigir na linguagem um tanto esotérica dos especialistas, para cuja leitura é prioritariamente direcionado.

Em contrapartida, os cientistas e tecnocratas - ressalvas feitas à distinção radical entre eles - enunciam suas promessas dentro de uma ideologia que associa bem-estar e superação do sofrimento à felicidade, e que encontra, na retórica atual das Ciências, em um final de século de absoluta exaustão psíquica, social, moral, um aliado poderoso no entusiasmo e clareza expressiva que caracterizam seu estilo. Diga-se o que quiser de Sokal \& Bricmont, mas na associação que fazem entre a necessidade da existência de evidência científica, a importância dos fatos e sua relação implícita com os (esquecidos) grandes projetos de transformação política (Sokal \& Bricmont, 1999), transpira alguma remotamente "engajada e legítima” preocupação com o social. Seu tom veemente, apaixonado e participativo remete a um esquecido idealismo (corresponda isto, ou não, a uma postura íntima por parte dos autores), refrescante principalmente - embora não apenas - para o público semi-leigo aquele que procura informação coerente e lazer com pitadas de auto-ajuda em doses quase equivalentes.
Na matéria da revista Veja "Superinteressante: autores de divulgação científica ameaçam tomar o espaço dos intelectuais na cultura" (Graieb, 1999), estes pontos são ressaltados. Cita-se, neste artigo, como expressivo desta tendência, o tipo de divulgação científica feito pelo agente cultural John Brockman. Em seu livro The Third Culture, Brockman (1996) defende a tese de que os cientistas que representa em contraste com "intelectuais do velho estilo" estão conscientes de "estar modelando os pensamentos de sua geração" (Brockman, 1996:1819). Aproveita, a seu modo, a queixa do historiador cultural Jacoby (1987, apud Brockman, 1996) de que a geração de pensadores atuantes na dimensão pública teria sido substituída por acadêmicos anêmicos, para justificar sua opinião de que um "intelectual é um sintetizador, um publicista, um comunicador" (Brockman, 1996:19). E define a "Terceira Cultura" - da qual é articulador - como consistindo "naqueles cientistas e outros pensadores no mundo empírico que, através de seu trabalho e exposições escritas, estão tomando o lugar da intelectualidade tradicional, tornando visível os significados profundos de nossas vidas, redefinindo quem e o que nós somos" (Brockman, 1996:17).

Naturalmente, o que está em questão é a promessa de uma eficácia explicitada de forma compromissada para com o indivíduo/grupo social. Na qual, os cientistas de ponta crêem, com base em dados empíricos, em seus laboratórios. Na qual, adeptos da transdisciplinaridades crêem, confiantes em, com o tempo, darem sustentação científica lato sensu às suas intenções éticas para intervenções significativas no mundo. A qual os pesquisadores das áreas humanas, academicamente bem renomados, repudiam, renunciando a um salto qualitativo em seus próprios esquemas mentais que pudesse levá-los à contribuição significativa que lhes é pedida por seus colegas cientistas e exigida pela sociedade. Desta forma, tanto a "aliança" superficial das transdisciplinaridades quanto a "guerra" das ciências naturais "triunfantes" versus ciências humanas "amarguradas" resolvem-se em uma derrota comum da Inteligência Humana. Com a entrega correspondente do que seria sua Potência aos mesmos mecanismos poderosos alienantes, na batalha contra os quais só sua Força conjunta teria chance de efetiva vitória. 


\section{A filosofia que deve dizer (em compasso de ação) do possível}

Uma das falhas estruturais do livro de Sokal \& Bricmont - em sua camaleônica crítica ao pósmodernismo - diz respeito ao tópico justamente em que eles não se detêm, que estaria na origem da "confusão intelectual" assinalada: a adjetivação constante das problemáticas, a exclusão da discussão de questões substantivas (confundidas com as "grandes narrativas", que não teriam mais lugar em nosso mundo de significações fragmentárias e multifacetadas), com freqüência assimiladas a entendimentos ontológicos e metafísicos e a juízos ético/morais estanques, predeterminados, de uma forma ou de outra, em função de valores estáticos e concepções abstratas inoperantes. À luz de nossa compreensão, pois, o equívoco fundamental da maioria dos autores criticados por Sokal \& Bricmont (e, neste sentido, cometeram algumas injustiças, nas quais não nos deteremos) estaria na falta de ter algo substantivo a dizer (ao menos nos textos escolhidos), o que os teria impulsionado a extrapolações de molde adjetivo para encobri-lo, donde seu estilo pesado, artificial e fátuo.

Em sua formação acadêmica contemporânea, o filósofo é cada vez mais estimulado a, para legitimar suas idéias, relacioná-las de alguma maneira às diversas Teorias do Conhecimento e/ou critérios epistemológicos. Da mesma forma, a Literatura deve pedir avais a exigências de modismos lingüísticos e à Teoria Literária e assim por diante. O que a princípio era de interesse das Ciências Naturais, para caracterizar certo discurso como científico - donde a importância do Círculo de Viena -, impôsse progressivamente às Humanidades, sufocando-lhes a primeira especificidade essencial: a do vigor da inspiração criativa.

Needleman (1983), em O Coração da Filosofia, comenta como, ao escolher o curso de Filosofia, estava interessado nas grandes questões como o Ser, a Realidade, o Sentido da Vida, e de que modo, gradualmente, foi sendo afastado - assim como seus colegas - do que o impulsionara pelas exigências menores de classificação e metodologias de ensino (que, embora em si tenham o objetivo oposto, por sua aplicação inadequada arriscam-se a ser experienciados como domesticações do pensar). Em trecho exemplar, Freud escreve a Lou-Andreas Salomé: "Para a minha velhice, escolhi o tema da morte. Defrontei-me com uma noção notável baseada em minha teoria dos instintos $e$ agora preciso ler todo o tipo de coisa a ela pertinente, como por exemplo, Schopenhauer, pela primeira vez. Mas não gosto de ler" (Freud \& Salomé, 1975:133). Tratava-se naturalmente da elaboração da pulsão de morte. Mas esse tipo de ímpeto que primeiro contata com uma Idéia - ou permite que ela surja de dado contexto auto-organizacional (para utilizarmos formulação mais atual) - e só depois busque sua validação no enquadre conceitual/metodológico vigente em dado momento/espaço é descategorizado a priori no "treino universitário". É neste sentido que Feyerabend "(...) ridicularizava a noção de propriedade intelectual e os padrões que obrigam o autor a referir o mais minúsculo e insignificante fato intelectual à sua fonte" (Feyerabend, 1998:188), devendo-se, ainda, registrar, de passagem, que, em sua apressada e superficialíssima crítica de Feyerabend, Sokal \& Bricmont negligenciam a assumida posição deste contra a pretensão farfalhante do discurso intelectualesco vazio, exortando a que seja mantida distância de "ofuscadores como Derrida" (Feyerabend, 1998:196).

A conseqüência disto que nos interessa pinçar para nosso comentário é a separação entre o Pensar e a Ação - interna, em primeiro lugar - a que esta mediação da necessidade de inserção em esquemas adjetivos obriga. Nos processos de elaboração interna, enfraquece-se o peso significativo da volição, instância que carreia em si o entusiasmo indispensável para forjar a ponte entre esta Ação interna e sua expressão externa no mundo. Cabe-nos aqui explicitar certa leitura do pragmatismo, que nos parece adequada ao entendimento de como se daria a dinâmica proposta.

Costuma-se entender mal o que seja pragmatismo, confundindo-o com o utilitarismo ou com a justificação teórica que é fornecida a estratégias de ação que se qualificam arbitrariamente como pragmáticas. Por pragmatismo entendemos aqui a orientação do pensar cuja tese principal é a de que toda verdade corresponde a uma regra de ação, a uma norma para a conduta futura, em que residiria o seu significado, entendendo-se por "ação" e "conduta futura" toda a espécie ou forma de atividade, quer seja cognitiva quer emotiva (Abbagnano, 1970:8). Nada tem a ver evidentemente com o materialismo, tendo sido, inclusive, enxertado no tronco da filosofia tradicional e utilizado para defesa do espiritualismo por William James, um de seus principais expoentes (Abbagnano, 1970). Pode também ser considerado "filosofia prática", que enfatiza o interesse na ação, não sendo classificável como "empírica" ou "a priori", "realista" ou "idealista" (Russell, 1967). Escusado é dizer que não se enquadraria em nenhum dos campos nos debates posi- 
tivismo versus relativismo. Dentro da multiplicidade de colorações de idéias dos autores dito pragmáticos, preferimos aqui privilegiar o que podemos chamar de "pragmatismo fraco": reconhece-se não estar em discussão a condição de se atingir uma Verdade absoluta, deliberadamente escolhem-se as crenças que seriam mais úteis para uma ação em dado contexto, em um universo pluralista ("multi-verso", segundo James) e atribui-se à vontade de viver o móvel propulsor do filosofar, na medida em que a ela submetem-se todas as lógicas.

Quando se repete a suspeita - comum em áreas de planejamento e administração pública - dos "produtos da atividade intelectual serem pouco efetivos no sentido de propiciar $\mathrm{mu}$ danças na sociedade em que (se) vive" (Castiel, 1999:2) cabe, antes de tudo, lembrar que esta é dúvida recente - não é provável que alguém questione a influência das idéias nas grandes revoluções do passado, da Francesa à Soviética - e indagar a que tipo de idéias nos estamos referindo. Não me parece que discussões eruditas sobre a justificação ou não - epistemológica? ontológica? lógica? cognitiva? - desta ou daquela hipótese de entendimento, assim como a constante asseveração de que as "forças ocultas" - políticas? astrais? - impedem qualquer alternativa de mudança, auxiliem a influência do Pensar - como fluxo e refluxo de Ação interna/externa - em transformações sociais, presumindo-se, é claro, que estas ainda sejam viáveis (pois, se não forem, para que escrever a respeito?).

Paquot (1999) descreve o quanto, atualmente, as utopias - aqui entendidas como as narrativas que corrigem os mecanismos sociais que regem as relações entre os indivíduos e a coletividade (Paquot, 1999) - não são mais sequer analisadas, sendo simples e radicalmente ridicularizadas. Embora tenham como ponto fraco a ausência de embasamento filosófico adequado, remetem a uma proposta interna corajosa, a de sair de um mundo codificado, indiferente e cínico "para aceitar perder o que temos e conquistar o que ignoramos (...)" (Paquot, 1999: 100). Para este autor, duas cenas podem ser entrevistas: a primeira, constata que o sistema global permite-nos parcos recursos de ação sobre nosso destino. A segunda, "tem raízes (...) na vontade de permanecer livre, de, teimosamente, viver e localiza-se nos indivíduos e grupos sociais que se recusam aos diferentes tipos de massificação e que (...) se religam, mais uma vez, às iniciativas críticas e positivas que os utopistas valorizavam." (naturalmente não se trata de "ressuscitar" as utopias!) Este tipo de projeto "opta pela política do possível, assume sua necessidade de reconhecimento, demonstra a seriedade de suas análises" (Paquot, 1999:106).

Henri Atlan é um exemplo de pesquisador que afirma seu compromisso com questões substantivas, não se isentando entretanto da justificativa epistemológica e das interconexões conceituais interdisciplinares que seu envolvimento teórico com o referencial da autoorganização lhe exigem. É a sua condição de aprofundamento em determinados tópicos do Pensar filosófico, dos quais escolhemos aqui a problematização do "possível", que o distingue também no campo das Humanidades. Ele se situa no espaço exigente e raro em que se dialoga com as diversas disciplinas sem perda de rigor formal e sem diluir, em meio a esta dinâmica, a precisão do enfoque, imprescindível para que as discussões em Fundamentos possam ser operacionalizadas. Desta forma recupera a sintonia interdisciplinar, segundo a perspectiva pela qual esta se faz fundamental nas reflexões em políticas públicas.

Atlan (1994) explicita que pretende propor "uma atitude pragmática" (Atlan, 1994:127), o que veremos concretizar-se, por exemplo, quando, ao defender a consideração de todos os possíveis face a cada situação de escolha, o faz baseado em “(a)ceitar o jogo de diversos sistemas interpretativos diferentes, científicos, mitológicos, artísticos, tendo o cuidado de não misturar as regras” (Atlan, 1994:233), e “(...) aceitando a pretensão de cada uma (das perspectivas) ao monopólio como uma regra do jogo, necessária ao desenvolvimento das partes" (Atlan, 1994:21). Todo o seu pensamento (no qual não nos deteremos aqui) filia-se a manter um conflito pulsante e produtivo entre as instâncias das possibilidades - com base, em termos de parceria interdisciplinar, na teoria do erro organizacional que ele aplica aos sistemas vivos (Atlan, 1992) indo ao encontro do que Paquot (1999) considera indispensável para romper a situação social atual de conformismo: uma retomada do conflito, no sentido em que uma sociedade igualitária necessita tanto dele quanto do acordo.

O grande diferencial da tese atlaniana é que, para ele, tal contenda tem uma clara e exclusiva dimensão pragmática, pois, através dela, remete a ser respeitado um princípio substantivo, o da Liberdade, que, de outra forma, não encontraria condições de expressão mental/material. É "regra das regras: não acreditar (numa ética e estética absolutas, pois se cairia na ideologia) (...) enquanto conteúdo do saber, sem excluir, no entanto, o otimismo na eficácia de sua prática" (Atlan, 1994:308). Pois, a partir de decisões dentro das dimensões do possível, “(a)inda que eivada de erros, de ilusões e de sa- 
beres imperfeitos, esta liberdade pragmática não deixa de ser menos real. Por um lado ela é eficiente e, por outro, pode instituir, pelo próprio fato de ter consciência de suas falhas, um horizonte de 'liberdade verdadeira', daquela que seria coincidente, no infinito, com um conhecimento total" (Atlan, 1991:212).

Concluímos, exemplificando brevemente a aplicabilidade de uma questão discutida nestes termos para a Saúde Pública. No caso, a revisão do constructo Possibilidade, enquanto servindo a uma discussão de Fundamentos. Conforme Atlan (1991), estreitou-se o entendimento de "possível" ao reduzi-lo, operacionalmente, a "potencial". É com este e não com aquele conceito que a Saúde Pública trabalha, em especial nos modelos de risco, em que a idéia de "potencial" de risco - em cima da qual todas as estratégias de prevenção e promoção de Saúde são montadas - se ressente de tal estreitamento, o que é comprovável em termos de sua baixa eficácia (Castiel, 1999). Não fazemos mais que esposar a postura pragmática ao afirmar que, onde uma ação no mundo se exprime de forma inadequada, inadequados também são os fundamentos da verdade-relativa que a justificam. Impõe-se, pois, a reconceituação de “possível”, sua re-inserção pragmática na teoria-prática de Saúde Pública, levando melhor em conta as infinitas variações em termos de erros e acertos nos processos do adoecer. Para tal, devemos deixar-nos guiar pelo entusiasmo da pesquisa destas vertentes inovadoras, recusando-nos a estagnar nos parâmetros já estabelecidos e restituindo ao Pensar filosófico sua dimensão de Criação concreta.

\section{Referências}

ABBAGNANO, N., 1970. História da Filosofia. v. 13. Lisboa: Presença.

ARAÚJO-JORGE, M. M., 1994. Da Epistemologia à Biologia. Lisboa: Piaget.

ATLAN, H., 1991. Tudo, Não, Talvez, Educação e Verdade. Lisboa: Piaget.

ATLAN, H., 1992. Entre o Cristal e a Fumaça: Ensaio sobre a Organização do Ser Vivo. Rio de Janeiro: Zahar.

ATLAN, H., 1994. Com Razão ou Sem Ela: Intercrítica da Ciência e do Mito. Lisboa: Piaget.

BOHR, N., 1995. Física Atômica e Conhecimento Humano. Rio de Janeiro: Contraponto.

BROCKMAN, J., 1996. Introduction: The emerging third culture. In: The Third Culture (J. Brockman, ed.), pp. 17-31, New York: Touchstone.

CARVALHO, A. I., 1996. Da saúde pública às políticas saudáveis. Ciência e Saúde Coletiva, 1:104-121.

CASTIEL, L. D., 1994. O Buraco e o Avestruz: A Singularidade do Adoecer Humano. Campinas: Papirus.

CASTIEL, L. D., 1999. A Medida do Possível... Saúde, Risco e Tecnobiociências. Rio de Janeiro: Contracapa Livraria/Editora Fiocruz.

CASTORIADIS, C., 1996. Les Carrefours du Labyrinthe IV: La Montée de l' Insignifiance. Paris: Seuil.

CASTORIADIS, C., 1999. Les Carrefours du Labyrinthe, V: Feito e a ser Feito. Rio de Janeiro: DP\& A.

DE DUVE, C., 1998. A Vida como Imperativo Cósmico. São Paulo: Campus.

DESCHAMPS, C., 1991. As Idéias Filosóficas Contemporâneas na França. Rio de Janeiro: Zahar.

ELIAS, N., 1990. O Processo Civilizador. Rio de Janeiro: Zahar. 
FEYERABEND, P., 1998. Matando o Tempo - Uma Autobiografia. São Paulo: Universidade Estadual Paulista.

FREUD, S. \& ANDREAS-SALOMÉ, L., 1975. Correspondência Completa. Rio de Janeiro: Imago.

FUJIMURA, J. H., 1998. Authorizing knowledge in science and anthropology. American Antropologist, 100:347-360.

GRAIEB, C., 1998. Queda da Bastilha: Autores denunciam asneiras de intelectuais franceses e fazem balançar o mundo acadêmico. Veja, 1578:146-148.

GRAIEB, C., 1999. Superinteressante: Autores de divulgação científica ameaçam tomar o espaço de intelectuais na cultura. Veja, 1587:123-124.

HEISENBERG, W., 1990. Páginas de Reflexão e Autoretrato. Lisboa: Gradiva.

KURZ, R., 1997. A estetização da crise. Folha de São Paulo, São Paulo, 23 nov. Caderno 3, p. 5.

KURZ, R., 1998. A expansão do caos. Folha de São Paulo, São Paulo, 6 set. Caderno 3, p. 5.

KURZ, R., 1999. A expropriação do tempo. Folha de São Paulo, São Paulo, 3 jan. Caderno 3, p. 5.

LASCH, C., 1986. O Mínimo Eu: Sobrevivência Psíquica em Tempos Difíceis. São Paulo: Brasiliense.

LAUDAN, L., 1990. Science and Relativism: Some Key Controversies in the Philosophy of Science. Chicago/London: University of Chicago Press.

MELLOR, F., 1999. Scientist rhetoric in the Science War. Public understand. Sci, 8: 57-63.

MORIN, E., 1996. O Problema Epistemológico da Complexidade. Mira-Sintra: Publicações Europa-América.
NEEDLEMAN, J., 1983. The Heart of Philosophy. London: Routledge \& Kegan Paul.

NICOLESCU, B., 1995.Ciência, Sentido e Evolução. São Paulo: Attar.

NUNES, E. D., 1994. Saúde coletiva; História de uma idéia e um conceito. Saúde e Sociedade, 3:5-21.

OMNĖS, R., 1995. Filosofia da Ciência Contemporânea. São Paulo: Universidade Estadual Paulista.

PAQUOT, T., 1999. A Utopia: Ensaio Acerca do Ideal. Rio de Janeiro: Difel.

POPPER, K. R. \& ECCLES, J. C., 1995. O Еu e seu Cérebro. Brasília: Editora da UnB/Papirus.

PRIGOGINE, I. \& STENGERS, I., 1991. A Nova Aliança. Brasília: Editora da UnB.

RANDOM, M., 1996. La Pensée Transdisciplinaire et le Réel. Paris: Dervy.

RUSSEL, B., 1967. História da Filosofia Ocidental. v. 3. São Paulo: Companhia Editora Nacional.

SNOW, C. P., 1993. The Two Cultures. Cambridge: Cambridge University Press.

SOKAL, A., 1996. Transgressing the boundaries: Toward a transformative hermeneutics of quantum gravity. Social Text, 46/47:217-252.

SOKAL, A. \& BRICMONT, J., 1999. Imposturas Intelectuais. Rio de Janeiro: Editora Record.

STURROCK, J., 1998. Le pauvre Sokal. London Review of Books, 20. 20 January 1999 <http://www.lrb.co. uk/v20n14/stur2014.htm>.

TOYNBEE, A. J., 1981. Toynbee por Ele Mesmo. Brasília: Editora da Universidade de Brasília.

VALLE-BARBOSA, W., 1990. Tempos pós-modernos. In: O Pós-Moderno (J. F. Lyotard, org.), pp. 7-13, Rio de Janeiro: José Olympio. 


\title{
Debate sobre o artigo de Ana Maria C. Aleksandrowicz
}

\author{
Debate on the paper by Ana Maria C. Aleksandrowicz
}

\section{Maria Cecília de Souza Minayo}

Centro Latino-Americano de Estudos de Violência em Saúde, Escola Nacional de Saúde Pública,

Fundação Oswaldo Cruz

\section{A propósito de imposturas e arrogâncias intelectuais}

Peço licença a Ana Maria Aleksandrowicz para limitar-me, no comentário de seu artigo, apenas ao campo das Ciências Sociais, onde caminho com um pouco mais de segurança. Entendo que, ao discutir as recentes publicações de Sokal e de Sokal \& Bricmont, a autora nos permite entrar em várias possibilidades de reflexão, porém, deter-me-ei em três delas, na medida em que as considero centrais no debate lançado pelos físicos em questão: (a) o status das Ciências Sociais e Humanas no campo científico e, por conseqüência, as relações entre as chamadas Ciências Naturais e as Ciências da Cultura; (b) os problemas de trans e interdisciplinaridade; (c) e, por fim, a questão da linguagem científica. Sobre cada um desses temas farei algumas considerações, a partir de minha própria experiência enquanto pesquisadora, orientadora, professora e leitora.

Partindo do princípio de que a origem da crítica e da confrontação entre campos científicos veio de um físico (que depois se associou a outro) em direção às Ciências Humanas e Sociais, poderia começar esse debate dizendo que não há novidade nesse confronto. Apenas esse ataque foi um pouco mais barulhento. Uma das maiores controvérsias que há no meio acadêmico é a cientificidade das Ciências Sociais em comparação com as Ciências da Natureza, para os que consideram a uniformidade de procedimentos e métodos, essencial na atribuição do estatuto de ciência a determinada área. A interrogação enorme em torno da cientificidade das Ciências Sociais tem várias razões. A primeira é se existe possibilidade concreta de tratarmos cientificamente de uma realidade, da qual, nós próprios, enquanto seres humanos, somos agentes. Essa ordem de conhecimento não escaparia radicalmente a toda a possibilidade de objetivação? A segunda, ao contrário, vindo dos que a praticam, se refere a que, buscando-se a objetivação própria das Ciências Naturais, não estaríamos descaracterizando o que há de essencial nos fenômenos e processos sociais, ou seja, negando o sentido profundo dado pela subjetividade? Em terceiro lugar, há os que interrogam sobre que método geral poderia explorar uma realidade tão marcada pela especificidade e pela diferenciação. Dizendo de outra forma, o dilema das ciências sociais frente ao campo científico hard seria seguir os caminhos das ciências estabelecidas e empobrecer seu próprio objeto, ou encontrar seu núcleo mais profundo e abandonar a idéia de cientificidade. A meu ver, é a proposta de cientificidade que tem que ser pensada como uma idéia reguladora de alta abstração e não como sinônimo de modelos e normas a serem seguidos. O labor científico, em qualquer área de conhecimento, caminha sempre em duas direções: em uma, elabora suas teorias, seus métodos, seus princípios e estabelece seus resultados; na outra, inventa, ratifica seu caminho, abandona certas vias e encontra outras. Sendo assim, há sempre um caráter de historicidade no conhecimento que também é construído e aproximado, como ensina Bachelard (1980).

Embora Sokal \& Bricmont não questionem o status das Ciências Humanas e Sociais, é claro o sentido de provocação que assumem seus textos, generalizando a crítica sobre a erudição superficial das Humanidades e das Ciências Sociais e, sobretudo, quanto ao uso apressado e banalizado de termos, conceitos e categorias das Ciências Exatas e Naturais, extrapolados para outros contextos. Nisso, os autores têm toda a razão e creio que devemos sempre tomar como bem-vindo o desvelamento das imposturas ditas acadêmicas, que têm produzido tantos intelectuais imbecis, inclusive diplomados. Por outro lado, será que não haveria um uso indevido, também por parte dos cientistas naturais, da linguagem utilizada para se referirem ao campo específico das humanidades e do social? Os próprios Sokal \& Bricmont se denunciam ao usarem o conceito histórico (e polêmico) de pós-modernidade como senso comum; e confundem os campos dos astrônomos com o da astrologia. Para não ir muito longe do nosso âmbito doméstico, basta olhar como se desconhecem, se estranham e se utilizam de forma banalizada, a epidemiologia e as ciências sociais no campo da saúde pública.

A epidemiologia, reconhecida ou exigindo para si o status de disciplina hegemônica da área em sua produção científica, freqüentemente utiliza os conceitos históricos mais caros às Ciências Sociais como se fossem "dados", ou seja, de forma reducionista e reificada. E, com certeza, as Ciências Sociais em saúde também se apropriam das descobertas e conceitos epidemiológicos superficialmente. Ousaria dizer, portanto, que essa produção simultânea de conhecimento e lixo acadêmico não é privilégio das Ciências Humanas e So- 
ciais, mas sim de todo o universo denominado por Popper (1975) Terceiro Mundo (não se trata da classificação sócio-econômica e política que assim nomeia os países subdesenvolvidos) para se referir à autonomia da sociedade científica com suas leis, normas, regras, formas de comunicação e de legitimação próprias. Assim caminha a ciência.

Estamos, portanto, frente a uma enorme questão da economia interna de cada uma e das relações entre as Duas Culturas, como denomina Aleksandrowicz, em referência ao termo utilizado pelo físico e romancista Snow. De um lado, cada campo tem seu lixo, sua impostura e sua compulsão à repetição. Vivencia também todos os embates e conflitos humanos e sociais relacionados ao poder, à concorrência e à legitimação: esses assuntos tão pouco científicos! De outro lado, mesmo em relação a nossas áreas de conhecimento, sabemos muito mal e pouco, pois quanto mais estudamos, mais perguntas e dúvidas nos assolam. Além disso, como nos ensina Shutz (1982), além de sabermos pouco, vivemos mesmo é com o senso comum. Tirando aquele pequeno espaço de saber científico, com exceção dos grandes sábios e gênios, nós nos movemos com o conhecimento que nos dá a experiência, aliás suficiente para vivermos em sociedade.

O segundo ponto que quero discutir é a questão da trans e da interdisciplinaridade. Sempre tive e tenho um problema para aceitar, na prática de pesquisa, o conceito acadêmico de transdisciplinaridade, pois seu sentido supõe a capacidade de ir além, transcender as disciplinas. Esse vôo remonta ao sábios da Biblioteca de Alexandria, quando propugnavam que a formação ideal do ser humano teria que juntar a Matemática (as ciências exatas), a Filosofia (que então ocupava o papel do conhecimento do homem e da sociedade) e as Artes. Era a idéia do múltiplo e do uno, ou do múltiplo no uno, tantas vezes tentada seja na concepção das universidades, seja por investigadores individuais, seja em grupos de pesquisa.

Essa verdadeira utopia do campo científico, tal como está constituído na modernidade, porém, tem sido cada vez mais postergada em sua realização, talvez por falta de investimento suficiente, fruto da mentalidade cartesiana e da fragmentação da ciência, ou talvez pela pequenez de nossa capacidade de aprender e apreender o todo. Na verdade há conceitos, há categorias, há temas transdisciplinares na medida em que atravessam áreas específicas. Porém significariam a mesma coisa em cada área? Por isso, repito, tenho muita dificuldade de trabalhar com o conceito de transdisciplinaridade, porque não consegui até hoje perceber os resultados frutíferos dessa proposta.

Ao contrário, valorizo e acho que o trabalho mais sério que podemos fazer em áreas como a da saúde pública, necessita fundamentar-se e se organizar de forma interdisciplinar. Qual é a diferença? Neste caso, os investigadores acreditam na especificidade das disciplinas, em sua construção histórica de conceitos, categorias e princípios e buscam uma forma de cooperação que supere as limitações disciplinares e permita conhecer temas e objetos de forma mais abrangente, juntando - por exemplo, no caso da Epidemiologia e das Ciências Sociais - a magnitude dos problemas e a sua compreensividade. Colaboram também na triangulação de métodos, respeitando a contribuição de cada um. Habermas (1987) nos fala que, nesse diálogo, são fragmentos disciplinares que se encontram, e Kant (1980) nos lembra que é no tema, no objeto, no fenômeno, que a síntese se realiza. Sinaceur (1977) comenta que só os grandes cientistas e sábios conseguiram dominar as dimensões do que Snow denomina as Duas Culturas. Sendo assim, considerar a possibilidade e a necessidade de construir e praticar a interdisciplinaridade (o que exige o reconhecimento das disciplinas e dos investigadores de ambas as áreas), parece-me ser um exercício de realismo e de reconhecimento de limites. Por isso, creio que procede a crítica de Sokal \& Bricmont quando se referem ao uso apressado, arrogante e mitificado de conceitos da física por parte de cientistas humanos e sociais, desconhecendo o sentido preciso e a adequação dos mesmos, construídos que foram por uma comunidade científica de longa historicidade. No entanto, faço a ressalva de que esse cuidado tem que existir de ambos os lados.

O terceiro ponto é a questão da linguagem científica. Em última instância, toda área científica se transforma em campo simbólico. Cada campo se legitima na medida em que consegue estabelecer uma linguagem fundamentada em conceitos, métodos e técnicas para compreensão do mundo, das coisas, dos fenômenos, dos processos e das relações. Essa linguagem, para ser reconhecida, tem que ser usada de forma coerente, precisa e instituída por uma comunidade que a controla e administra sua reprodução e suas mudanças. Deste modo, como veículo das descobertas e de todas as ações empreendidas para realizá-las, cada área tem o seu jargão, que não pode impunemente ser apropriado por outra. A historicidade das atividades científicas expressa-se nos produtos-objetos e no discurso teórico que descreve, compreende e explica. A Ciência é, na verdade, uma 
construção humana - inclusive, historicamente datada - e uma construção social, porque é feita pelo coro de muitas vozes, pelo labor de muitas mãos e pelo encontro espiritual de muitos cérebros. Porém, sua tradição se expressa na linguagem que conta seus acúmulos, suas repetições, suas superações e suas mudanças de paradigma. Procedem, portanto, as críticas de Sokal \& Bricmont quando mostram os exageros da fenomenologia sociológica - que considera a realidade como mero fruto de representações sociais - e o construtivismo radical que só percebe a realidade como uma narrativa, desconhecendo a substância dos fenômenos. Tais exageros tiveram sua forma de expressão muito forte nos primeiros discursos construtivistas sobre AIDS, em nossa área. Muitos analisavam essa síndrome como mera construção social, um novo mito, exacerbando o sentido do estigma que certamente contribuiu e contribui para o agravamento desse fenômeno primeiramente biológico. Talvez, os termos corretos para se apresentar o problema teriam sido os de Latour (1994) quando fala no híbrido biológico-social.

Mas há um outro sentido na crítica da linguagem, feita por Sokal \& Bricmont. É o caso da ostentação e da erudição superficial, segundo eles, motivadas por todos os problemas que comentamos acima. Neste ponto creio também que têm razão. Infelizmente, também nas Ciências Sociais é muito comum a divulgação de textos cuja construção parece ter o propósito de marcar a diferença com os não iniciados. Usando um rebuscamento desnecessário para dizer coisas muito simples, alguns buscam impressionar os leitores cientistas e não cientistas incautos. Sobre isso, gostaria de comentar que, desde a faculdade, tomei como rumo em minha vida acadêmica, cultivar a linguagem clara e o mais possível, acessível. Por experiência e convívio no meio científico, cheguei à conclusão de que o rebuscamento, o jogo de linguagem, a manipulação de frases, freqüentemente (para não dizer sempre) escondem problemas dos próprios autores que, ou não dominam o assunto e se escondem atrás de citações (alguns são incapazes de construir uma frase sem a conclusão de citar autores), das palavras e dos jargões; ou têm dificuldade de síntese. Mas também aqui, eu não sei se o vício é só dos humanistas e cientistas sociais. Pareceme que os cientistas naturais são mais econômicos em seus trabalhos. De qualquer forma é preciso lembrar que a comunicação científica necessita da retórica para poder circular e repercutir. A medida certa dessa linguagem deve ser preocupação de todas as disciplinas.
Enfim, concluindo, quero agradecer a oportunidade que Ana Aleksandrowicz me deu de poder discutir, a partir dela, os textos de Sokal e Sokal \& Bricmont. Considero que quem está no campo acadêmico, na verdade, necessita de um constante e duradouro exercício de humildade. Perdoem-me pelo uso da categoria religiosa, mas não tenho outra palavra. Necessitamos estar abertos para ouvir críticas e perceber onde elas nos atingem e são pertinentes. Na verdade, nós, das Ciências Sociais, temos sido freqüentes autores e leitores de propostas com baixa qualidade e sentido, transvestidas de cientificidade. Temos abusado da linguagem erudita para esconder trabalhos repetitivos e exegéticos apenas (como nos chama atenção a frase de Montaigne usada por Ana Maria como epígrafe de seu trabalho).

Por um lado, o trabalho de campo, o contato com a realidade que pretendemos conhecer e compreender, nos ajudariam a melhorar nossa qualidade intelectual e a definir melhor nosso papel social. Por outro, além de humildes, temos que repudiar todas as imposturas e arrogâncias, inclusive essa que autores como Sokal e Sokal \& Bricmont, sob o pretexto de estabelecerem a ordem científica, nos impigem. Não é necessário tentar destruir com o discurso de um campo do conhecimento, as conquistas realizadas por outro. Também os cientistas naturais necessitam de humildade, ao se aproximarem do patrimônio histórico e acadêmico construído a duras penas tanto por clássicos como por laboriosos estudiosos do campo da Filosofia, das Ciências Humanas e Sociais. Que bom se a linguagem usada para diferenciar e distinguir, pudesse ser usada também cooperar e construir! Creio que a sociedade sinceramente agradeceria.

BACHELARD, G., 1980. O Novo Espírito Científico. Rio de Janeiro: Tempo Universitário.

HABERMAS, J., 1987. Teoría de la Acción Comunicativa. Madrid: Taurus Ediciones.

KANT, I., 1980. Crítica à Razão Pura. Coleção Pensadores. Rio de Janeiro: Editora Abril.

LATOUR, B., 1994. Jamais Fomos Tão Modernos. Rio de Janeiro: Editora 34/Literatura SC.

POPPER, K., 1975. Conhecimento Objetivo. Belo Horizonte: Editora Itatiaia.

SHUTZ, A., 1982. A common sense and scientific interpretation of human actions. In: Collected $\mathrm{Pa}$ pers I (A. Brodersen, ed.), pp. 29-63, 2nd Ed., New York: Martines Niphoff Editions.

SINACEUR, M. A., 1997. Qu'est ce que l'interdisciplinarité. Révue Internationale de Sciences Sociales, 29:617-626. 


\section{Antonio J. S. M. Domingues}

Centro Federal de Educação Tecnológica Celso Suckow da Fonseca

\section{As condições do diálogo}

Ao ser convidado a participar do debate motivado pelo artigo A extensão da impostura, de Ana Maria Aleksandrowicz, vi-me não só diante da oportunidade de expressar algumas reflexões relativas ao diálogo interdisciplinar - tema maior tanto do livro de Sokal \& Bricmont quanto do presente artigo -, mas também diante da necessidade de, sendo físico por formação e, portanto, oriundo de área distinta das dos demais debatedores - o que, oportunamente, faz deste um debate interdisciplinar -, ser cuidadoso com as palavras e idéias por mim aqui apresentadas. Este cuidado se faz necessário não por questões de prudência ou de auto-preservação, mas para que a qualidade da discussão não seja comprometida por alguma falta de clareza, já que, conforme é bem sabido, a não coincidência do universo vocabular vem a ser justamente uma das características principais do diálogo interdisciplinar.

Toda a problemática levantada por Sokal e Bricmont e aqui debatida por Aleksandrowicz envolve uma miríade de aspectos - da questão do pós-moderno à disputa de poder nos meios acadêmicos, da discussão acerca da real natureza do método utilizado nas ditas ciências naturais ao status epistemológico da hermenêutica gadameriana - defendida por várias áreas das chamadas humanidades -, ou ainda dos usos e abusos na transposição dos discursos das diferentes áreas ao debate sobre a natureza objetiva, subjetiva ou intersubjetiva do que chamamos de Realidade. Gostaria, contudo, de focar a atenção em alguns aspectos de um tópico aparentemente mais simples que os acima citados, mas que, devidamente considerado, traz alguma luz à discussão: o das condições de possibilidade do diálogo interdisciplinar.

Uma destas condições, já mencionada, é o cuidado com a terminologia. Quando dialogamos - mesmo no dia-a-dia - com alguém com quem não estamos habituados a dialogar, é conveniente estar atento para o fato de que alguma palavra utilizada pode não ter o mesmo significado para ambos os interlocutores. Se tal acontecer, não teremos nem a oportunidade de discordar, pois não estaremos sequer nos compreendendo. É possível, no entanto, que tal situação aconteça sem nos darmos conta - neste caso, estaremos na lamentável situação de acharmos que discordamos - ou concordamos(!) - com nosso interlocutor, quando, na verdade, sequer houve comunicação - no sentido pleno do termo. É justamente esta possibilidade que torna imperativo o cuidado com o significado dos termos empregados por ambas as partes. Este esforço, este cuidado em prol da maior clareza possível é justamente o que chamamos de rigor.

Alguns poderiam questionar esta última afirmação, discordando de que a noção de rigor possa ser (meramente) identificada com a de clareza terminológica. De fato, o termo também é utilizado com referência à correção de um raciocínio ou à coerência de determinada linha de argumentação com seus pressupostos metodológicos. Contudo, creio que a identificação permanece válida se nos referirmos à clareza em qualquer sentido, e não apenas clareza terminológica. Um texto rigoroso é, essencialmente, um texto claro.

Pois bem, se mesmo em um diálogo cotidiano este tipo de cuidado é bem-vindo, maior ainda será a necessidade de rigor - ou seja, de esforço em prol da mútua compreensão - quando se trata do diálogo interdisciplinar, pois neste caso estamos lidando não apenas com terminologias diferentes mas com escolas de pensamento verdadeiramente distintas, com história e cultura próprias, com tradições complexas e muitas vezes seculares. Cada um dos participantes de um debate interdisciplinar é um iniciado de uma destas escolas, na qual ingressou através de anos de convívio com seus pares, em um processo ao longo do qual - além da terminologia própria de cada área - uma enorme quantidade de pontos de vista é internalizada, adquirindo-se assim o modo de pensar e sentir o mundo típico daquela disciplina. (Uma das delícias do diálogo interdisciplinar vem a ser justamente a possibilidade de percebermos, em nós mesmos, esses pontos de vista - enquanto tais - uma vez que, ao dialogar com nossos pares, não nos damos conta da maioria deles).

Há aqui um ponto a ser abordado. Pessoalmente, não vejo por que deveríamos considerar como válidas para o diálogo interdisciplinar, entre as escolas de pensamento mencionadas no parágrafo anterior, apenas aquelas tradicionalmente tidas como acadêmicas. Seria, com certeza, um equívoco supor que sejam irracionais as linhagens que se apoiam na tradição ou em determinadas práticas e/ou experiências partilhadas por seus membros, ou em valores e/ou pressupostos coletivamente assumidos - cada uma dispõe de um corpo de saber internamente coerente e, portanto, é dotada de uma racionalidade que lhe é própria que não somos obrigados a aceitar, mas com a qual podemos dialogar.

Mas, se não comungamos daquela visão de mundo, por que dialogaríamos? Mas este é jus- 
tamente o cerne do conceito de diálogo interdisciplinar: queremos ouvir o que tem a dizer aquele que pensa diferente de nós. Por quê? Porque estamos interessados em ouvir, conhecer, compreender um pensamento outro, que nos enriquecerá - talvez fecundando nosso próprio pensamento, talvez não, mas sempre ampliando nossos horizontes conceituais. Quando Jung dialoga com a tradição do tarô, quando um psicólogo conversa com um monge zen sobre estados mentais, quando um médico busca compreender técnicas xamânicas, o que ocorre são diálogos interdisciplinares perfeitamente legítimos. Não há por que pensar que tais iniciativas sejam perigosas, inoportunas, de mau gosto ou empobrecedoras; antes, ao contrário - desde que ambos estejam, de fato, dispostos a dialogar.

A disposição para o diálogo se faz necessária por uma razão simples: se o debate em questão for verdadeiramente interdisciplinar, o olhar de cada um sobre o objeto discutido será essencialmente diferente. Se, por exemplo, um espírita umbandista e um psicólogo profissional assistem em conjunto a uma sessão onde um médium vivencia um incorporação, do primeiro ouviremos então que a entidade incorporou, enquanto que o segundo opinará, talvez, tratar-se de manifestação do inconsciente. (É oportuno notar que ambos estão observando a mesma cena - ou não? -, da mesma forma que os antigos observavam, a olho nu, os mesmos fenômenos celestes que nós, e viam neles a comprovação de que a Terra é o centro do Universo, enquanto nós vemos, nestes mesmos fenômenos, a comprovação de que o Sol é o centro do Sistema Solar. Do mesmo modo, quando os cientistas do início do século XVIII contemplavam os fenômenos relacionados ao calor, eles viam o calórico - a substância do calor fluir entre os corpos materiais. Hoje observamos os mesmos fenômenos e, ao mesmo tempo, afirmamos que tal substância não existe).

A tarefa é, portanto, mais delicada - mas também mais fascinante - quando os interlocutores são representantes de diferentes disciplinas ou campos conceituais. O desafio para que a comunicação verdadeiramente ocorra, inclui não somente o cuidado com os termos utilizados, mas também um esforço para compreender - para adquirir, de fato - o olhar do nosso interlocutor sobre o objeto em questão. Se tal não se der, correremos o risco de, mesmo dominando todos os termos utilizados - no sentido dicionaresco da palavra -, estarmos novamente na situação de achar que discordamos ou concordamos - com nosso interlocutor, sem que o tenhamos sequer compreendido.
Enfim, ao debater o tema das condições do diálogo interdisciplinar, convém lembrar que o esforço em prol da mútua compreensão, que tão bem o caracteriza, é contudo freqüentemente minado por diversas circunstâncias, bastante familiares a quem tem, no meio acadêmico, o seu cotidiano. Muitas vezes estamos por demais interessados em defender nossos interesses paroquiais, nosso prestígio junto aos pares; ou buscamos, mesmo que inconscientemente, proteger - atavicamente, como quem protege um bem precioso de uma grande ameaça - as idéias e visões de mundo sobre as quais se apoiam nossa própria trajetória - seja esta uma opção religiosa, a carreira acadêmica que porventura abraçamos, ou as crenças que norteiam nossa maneira de viver -; ou, ainda, não dispomos de tempo para desperdiçar com idéias evidentemente fantasiosas e/ou supersticiosas e/ou equivocadas e/ou mal intencionadas, a não ser que seja para desmitificá-las, ou denunciá-las, ou para, bem intencionados, esclarecer o equívoco de seus proponentes.

Contudo, se optarmos por desconsiderar circunstâncias intrinsecamente estranhas ao legítimo diálogo interdisciplinar, tais como as citadas no parágrafo anterior - ou ainda pura e simples má fé, motivada por disputas de poder, vaidade ou oportunismo acadêmicos - é possível colocar a situação analisada por Sokal \& Bricmont e Aleksandrowicz nos seguintes termos: os autores e pensadores apontados por Sokal \& Bricmont não teriam feito o dever-decasa de compreender adequadamente as idéias propostas pelas Ciências Naturais - ou seja, da maneira como estas mesmas ciências as vêem. Assim, poderíamos dizer que o problema está não na transposição em si de termos e conceitos das ciências naturais para outros contextos - como Sokal \& Bricmont e outros críticos parecem sugerir -, uma vez que a fecundação mútua dos saberes tem sido, ao longo dos tempos, uma das principais fontes de enriquecimento das diversas disciplinas. O problema estaria antes no simples fato de que não é possível transpor ou dialogar com idéias que não foram verdadeiramente compreendidas, sejam estas oriundas de outra área do saber ou não. (Isto não implica, contudo, necessariamente em má fé, pois é possível, conforme vimos, acreditar que compreendemos adequadamente as idéias em questão - sem que na realidade o tenhamos feito - e portanto acharmo-nos em condições de transpô-las para outros contextos, ou de com elas debater).

Ocorre que, se de fato é essa a natureza da situação analisada, é preciso então chamar a atenção para um aspecto quase nunca mencio- 
nado: o da responsabilidade da comunidade científica de Ciências Naturais, especialmente dos físicos, para com este estado de coisas. Nos últimos vinte e cinco anos, principalmente a partir da publicação de $O$ Tao da Física, de Fritjof Capra (1975), o grande público teve sua atenção atraída para o fascínio que certas áreas da Física Moderna exercem, notadamente a Física Quântica. A isto seguiu-se um grande número de títulos que se propunham a apresentar, de modo acessível a leigos, a natureza destas novas idéias. Embora muitos deles apresentassem um cunho algo sensacionalista, diversos vieram a público pelas mãos de cientistas renomados - Uma Breve História do Tempo, de Stephen Hawking (1988), é apenas um entre muitos exemplos.

Estes autores, contudo - salvo rara exceção - não lograram atingir o objetivo proposto. Talvez seja possível atribuir, em larga medida, a situação descrita por Sokal \& Bricmont a este fato: os representantes da comunidade científica fracassaram - sem perceber! - em sua tentativa de esclarecer, junto ao grande público - bem como junto aos acadêmicos das demais áreas as idéias da nova Física. Paralelamente, grande parte do conjunto de leitores não percebeu que de fato não as havia compreendido. Não há paradoxo algum no que acabou de ser dito, nem acusações de má fé ou incompetência a quem quer que seja: simplesmente a grande maioria de nós, acadêmicos ou não, não está consciente das sutilezas do diálogo interdisciplinar.

Esta situação - escrever livros para público leigo - pode ser pensada como um tipo de diálogo interdisciplinar, no qual falamos para um interlocutor que sabemos não ser de nossa área, mas de quem não ouvimos nenhuma resposta (perdendo assim não somente o melhor da festa, como também a possibilidade de verificar se de fato nos fizemos entender). O livro de Stephen Hawking é, neste caso, um bom exemplo. $\mathrm{O}$ autor considera que, por não utilizar equações matemáticas e por fazer uso freqüente de analogias ao longo do texto, este se torna compreensível ao público não especialista. Ocorre que a Física está repleta de termos técnicos que também estão presentes na linguagem coloquial, porém com significado bastante distinto, tais como energia, onda, interferência, superposição, limite, crítico (como em massa crítica) etc. Além disso, para o especialista que há muitos anos vive naquele ambiente, diversas noções - muitas vezes extremamente sutis - tornaram-se, ao longo dos anos, tão familiares que já não é natural dar-se conta de que houve um dia em que não pensávamos desta forma, de que para um leigo este olhar não é natural. Esta percepção, este aprendizado da diferença, vem justamente do contato direto e continuado com interlocutores de outras áreas, o que freqüentemente o acadêmico altamente especializado não tem (Não obstante, convém ressaltar que, para quem tem formação na área, o livro de Stephen Hawking é ótimo).

Como vemos, são demais os perigos desta vida. Lembrei-me agora dos debatedores mencionados acima, o espírita e o psicólogo, que estavam para iniciar um diálogo interdisciplinar, com todas os desafios inerentes a este. Supondo, porém, que nossos dois personagens consigam evitar todas essas circunstâncias, resta ainda uma pergunta: por que debateriam? Para atingir, em algum momento, a certeza absoluta a respeito da natureza do transe mediúnico? Não, certamente que não. Tal coisa - a certeza absoluta - não existe, pois não há critério absoluto de verdade (disto não se segue necessariamente, convém observar, que a noção de verdade - e por conseguinte a de realidade seja por natureza a de algo construído, e não descoberto, por carecer de qualquer objetividade. Afirmações nessa direção, normalmente associadas ao pós-modernismo, são objeto de intensa polêmica). Por que, então, debateriam eles? Porque é isso que nos move. Porque nos interessa a opinião que é distinta da nossa. Porque esse foi o nosso movimento desde o princípio, por isso nos tornamos investigadores. Porque essa sempre foi - pelo menos quando começamos - a natureza da busca, do nosso interesse pelo mundo e pelas idéias. Quem investiga algo, o faz como quem quer descobrir a verdade a respeito desse algo. Conseguiremos? No sentido de ter certeza absoluta, jamais. Valerá então a pena? Todos nós sabemos que sim. A jornada do conhecimento é uma das maiores fontes de alegria da vida humana. Não é a única, nem a mais importante. É trabalhosa e cheia de armadilhas, mas é linda - e é por isso que estamos todos nela.

CAPRA, F., 1975. O Tao da Física. São Paulo: Editora Cultrix.

HAWKING, S., 1988. Uma Breve História do Tempo. Lisboa: Gradiva. 


\section{Mara Helena de Andréa Gomes}

Departamento de Medicina Preventiva Escola Paulista de Medicina, Universidade Federal de São Paulo
Quero ressaltar, antes de tudo, a coragem da autora na escolha de dois eixos para comentar o livro de Sokal \& Bricmont. As incontáveis provocações feitas por estes autores aos cientistas sociais, mais do que às próprias Ciências Humanas, não deixa de constituir uma maneira relativamente escamoteada com que se esquivam de enfrentar questões internas fundamentais não só para estas, como para a ciência como um todo. As críticas de Sokal \& Bricmont aos cientistas humanos acabam por respingar no próprio campo de conhecimento específico (nem mais nem menos notável por tal especificidade) destas ciências, tamanho o alvo que escolheram para disparar generalizações (a este respeito, que motivo terá conduzido os editores brasileiros a acrescentarem um subtítulo tão amplo e categórico?) e generalidades, com algumas das quais aliás, dadas a obviedade e validade para qualquer campo, somos cooptados a concordar. Não deve ter sido fácil, portanto, escolher o caminho de exposição percorrido nesse louvável esforço intelectual.

Embora seja tentador diversificar os eixos escolhidos por Aleksandrowicz, tentarei comentar o texto em torno de sua busca por apontar "uma resposta significativa" às críticas de Sokal \& Bricmont; busca com a qual, digase, talvez tenha se colocado na plena, mas nem tão sutil, armadilha dos autores. Concordo plenamente com a alegada necessidade de respostas, por parte das Ciências Humanas, não diretamente aos autores das Imposturas, mas aos problemas sociais postos pela e para a humanidade ao longo dos tempos - e o desenvolvimento científico é um deles, sobretudo em sua relativamente recente associação histórica ao desenvolvimento tecnológico.

O que está em questão, afinal? Parece-me que é a recuperação de um certo entrelaçamento proposto há muito tempo (pelos chamados "modernos" e alguns "pós-modernistas", justiça seja feita a uns e outros e usando as designações de Sokal \& Bricmont), entre distintos campos de conhecimentos, em um plano que não se configura na imediatez destas práticas científicas, mas em um nível necessariamente descolado de todas elas. Como será possível essa reflexão sem levarmos em conta todas as necessárias mediações materiais, sociais e simbólicas aí embutidas? Se, até o momento, a especialização é o produto social e histórico mais acabado daquele desenvolvimento, as dificuldades dela derivadas, por um lado, impedem-nos de reconhecermo-nos uns aos outros e em todos esses planos que dizem respeito ao local, regional, nacional - cultural, enfim. Por outro lado, conduzem-nos a lidar com estas questões, quer sejamos ou não cientistas (humanos, sociais, naturais, biológicos...).

Não terá sido por acaso, portanto, o referido apelo esperançoso à parceria entre a Física e a Filosofia apontado pela autora. No interior desta parceria, as Ciências Sociais e Humanas ocupam um lugar subsidiário - mas não necessariamente subordinado -, cabendo-lhes elaborar as mencionadas intermediações na atual divisão intelectual do trabalho, decorrência do também indicado "movimento irreversível da Cultura”. Neste contexto de mediações e práticas, a interdisciplinaridade não é apenas um apelo, mas algo constitutivo deste amplo campo, necessariamente marcado por um trânsito tão contínuo quanto (in)tenso entre elas.

No que concerne à proposta de transdisciplinaridade em tempos tão especializados, Sokal \& Bricmont têm lá suas razões: todo cuidado é pouco quando se trata de transitar entre campos conceituais cujos significados e sentidos podem ser mais ou menos explicativos para determinado referencial, mas não para todos. Para ficarmos no campo da sociologia, Durkheim (1972, 1977), por exemplo, criou sua "morfologia" e "fisiologia social" com a crença e o intuito de assim poder institucionalizá-la de maneira aceitável para a chamada comunidade científica. Mas, ao re-significar para a Sociologia conceitos retirados da Biologia, não só apontou a necessidade desse cuidado como o fez de maneira coerente para sua teoria explicativa, concordemos ou não com seus demais postulados. Nem por esta razão deixou de ser acusado de organicista por outros cientistas sociais, também eles com suas razões.

Para Weber (1969, 1983, 1989), outro clássico exemplo, aquele contínuo transitar pode ser compreendido como luta pelo poder, luta responsável pelo movimento da História. Do ponto de vista formal, na concepção weberiana o conceito de poder é categoria sociologicamente amorfa, sempre requerendo uma qualificação. De qualquer modo, este constitui o traço social mais característico da humanidade, sobretudo na atualidade, quando o poder intelectual e especializado promove tantas lutas, dentro e fora das universidades. Nestas, como sabemos, este poder é denominado por Weber de mandarinato, e não por acaso.

Mais recentemente, Bourdieu (1984) e Bourdieu et al. (1988) fizeram extensa pesquisa em universidades francesas, apontando os critérios de distribuição de poderes que conferem prestígio e projeção intelectual e social, não só conforme os campos de saberes, mas no interior de cada um deles. Para os objetivos do tex- 
to aqui comentado, é interessante seu conceito de vigilância epistemológica. Não me parece que Bourdieu esteja parafraseando a conhecida prática de saúde pública, mas alertando os sociólogos para um constante estado de alerta quando se trata de tentar elaborar aquelas mediações. Mas re-significar, mesmo com todas as ressalvas contidas em suas notas de rodapés, passam ao largo destas preocupações, conduzindo leitores menos avisados a pensar que não fazem parte do métier das Ciências Sociais.

$\mathrm{O}$ fato é que o apelo à interdisciplinaridade vem sendo feito ao longo dos tempos, intensificando-se com o processo de especialização. Daí minha concordância e minha discordância com a autora no que diz respeito à Guerra das Ciências. Se a Ciência é generalizadora e porta consigo um ideal universalista, ela própria não escapa da sua principal conseqüência - as especializações e especialidades, com toda a complexidade que esse processo carrega.

Neste parâmetro, o simples ato de transcrever a expressão "Guerra das Ciências" é mesmo infeliz, não novamente pelos motivos apontados por Sokal \& Bricmont, mas por conduzirnos a pensar a diversidade de conhecimento como prática apenas belicosa, quando poderíamos ver aí algo constitutivo da humanidade - lutas e alianças incluídas - e, mais particularmente, do pensamento científico. Pois, mais do que antes - e como bem aponta a autora -, do ponto de vista histórico, o apelo à interdisciplinaridade pode ser tomado como necessidade de cooperação, até por promover questionamentos mútuos que podem ter um sentido mobilizador. Tanto é ardilosa a utilização da referida expressão, que Aleksandrowicz acaba reproduzindo outras (tais como "entre os cientistas" e "cientistas") para efeito de diferenciação em relação às "Humanidades". Só encontramos as "humanas" afirmadas de maneira autoral como ciências muito adiante no texto, em uma formulação ambígua: a quê/quem a autora se refere? Outras perguntas, à guisa de comentários: por que, afinal, tanta polêmica em torno da cientificidade das ciências sociais e humanas? Será assim tão ameaçador à Ciência o fato de estas serem ou não ciências?

Busquemos, no próprio texto em debate, as indicações que merecem reflexão, tomando o segundo eixo de discussão proposto. À defesa do pragmatismo filosófico necessário ao discurso - e por que não às práticas? - das "Humanidades", podemos acrescentar outra pergunta, ainda, até com versão musicada - "existirmos, $a$ que será que se destina?” (Caetano Velloso, letra e música de "Cajuína”) - pergunta que não deixa de "remeter a uma proposta interna corajosa", no dizer da autora, em sua feliz apropriação de
Paquot. Este campo de conhecimento, genericamente designado de "humanidades", é também constituído por ciências que lidam com valores engendrados pelos seus respectivos "objetos": as relações sociais, em suas variadas concepções conforme a Ciência Social em questão e o autor em consideração. Resvalam sempre questões valorativas, de caráter ético, moral, filosófico, simbólico e também científico-tecnológico. Propor "soluções [de eficácia... e ... de intervenções significativas no mundo] para os dilemas que esmiuçam" (grifo do autor) não é formulação originada no campo das ciências sociais nem poderia ser enquanto campo de intermediações, muito embora reconheçamos a sua relevância para o dilemático campo de intervenções da Saúde Pública.

Na perspectiva mais geral das Ciências Sociais, soluções deste tipo devem ser negociadas, pactuadas, consensuais e reformuladas processualmente (são históricas por natureza e políticas por pressuposto), dado que esta busca é impregnada de conflitos. E neste plano de generalização, o conflito não se restringe a este ou aquele modo de organização social, como poderíamos pensar, mas como algo que se apresenta, para as Ciências Sociais, como inerente a qualquer organização social. Mesmo que o seja em uma sociedade igualitária, como queremos, traz à tona um outro debate: o do contrato social entre protagonistas antagônicos na maior parte das vezes, debate em torno do qual Sokal \& Bricmont pouco ou nada contribuíram na obra comentada. Já a busca metódica e sistemática de "consistência teórica elou objetividade operacional”, por seu lado, faz parte do próprio aprendizado desse campo. Transversalmente a esse aprendizado e sem nenhuma exclusividade das Ciências Sociais, podemos construir instrumentos de ação política necessários para a realização das utopias que incorporem, pelo menos, os valores da igualdade com liberdade. Em consonância com aquele tipo de ação, estes valores podem constituir de fato ameaça aos poderes descritos.

BOURDIEU, P., 1984. Homo Academicus. Paris: Les Éditions de Minuit.

BOURDIEU, P.; CHAMBOREDON, J.-C. \& PASSERON, J.-C., 1988. El Oficio de Sociólogo. Presupuestos Epistemológicos. México, D.F.: Siglo XXI.

DURKHEIM, E., 1972. Regras do Método Sociológico. São Paulo: Companhia Editora Nacional.

DURKHEIM, E., 1977. O Suicídio. Um Estudo Sociológico. 2a Ed. Lisboa: Editorial Presença.

WEBER, M., 1969. Economía y Sociedad. Esbozo de Sociología Comprensiva. México, D.F.: Fondo de Cultura Económica.

WEBER, M., 1983. Fundamentos da Sociologia. 2a Ed. Porto: Rés.

WEBER, M., 1989. Sobre a Universidade. São Paulo: Cortez. 


\section{Alberto Lopes Najar}

Departamento de Ciências Sociais, Escola Nacional de Saúde Pública, Fundação Oswaldo Cruz najar@ensp.fiocruz.br
"It was the best of times, it was the worst of times, it was the age of wisdom, it was the age of foolishness, it was the epoch of belief, it was the epoch of incredulity, it was the season of Light, it was the season of Darkness, it was the spring of hope, it was the winter of despair, we had everything before us, we had nothing before us, we were all going direct to Heaven, we were all going direct the other way - in short, the period was so far like the present period, that some of its noisiest authorities insisted on its being received, for good or for evil, in the superlative degree of comparison only" (Dickens, 1985:35).

O chamado diálogo entre as "Duas Culturas" sempre nos atormentou. Será profícuo o investimento intelectual para resolvê-lo? Parece-nos que os efeitos colaterais deste debate são mais férteis do que o debate em si. O que se esclarece, encontra-se mais nos argumentos periféricos do que nos principais. A relação entre as ditas duas culturas sempre foi bastante tensa e parece-nos - assinala uma dicotomia de nossa coalização civilizatória. Periodicamente aciona-se a mó deste debate. Feitas as contas, após um certo relaxamento das placas tectônicas, o que resulta? Talvez a objetivação de certos princípios e a explicitação de alguns padrões.

Talvez as Duas Culturas sejam mundos possíveis, mas diferentes, que habitam os profundezas do ser e, a nosso ver, se forem compreendidos como tal, resolve-se o lado estéril e histriônico do debate. É difícil para a cultura ocidental lidar com este estresse cognitivo. Esta dificuldade nos tem conduzido a diversos becos - que não cabem aqui explicitar - e, nesta perspectiva, a epígrafe da autora é irretocável.

Do ponto de vista histórico convém lembrar três momentos de aproximação. Primeiramente, a característica marcante do século XVII no campo da investigação científica: a busca do método que permitisse a constituição de legítimo e seguro conhecimento. Nesta direção se alinham diversos escritos importantes: Novum Organum (Bacon, 1561/1626); Tratado da Reforma da Inteligência (Espinosa, 1632/1677); A Procura da Verdade (Malebranche, 1638/1715); e diversos opúsculos de Leibniz (1646/1716).

Em segundo lugar há o "pecado original”, se assim nos for permitido expressar, que marca o nascimento da sociologia, avant la lettre: em seu prefácio ao Espírito das Leis, Montesquieu (1689/1755) assinala que depois de examinar o comportamento dos homens, percebeu que a infinidade de leis e costumes não eram orientadas apenas por seus caprichos, mas, ao contrário, através de relações necessárias que deri- vam da natureza das coisas, sendo estas relações, expressões de quatro Leis primordiais, quais sejam: busca da paz, procura de alimentos, reprodução e vida em comunidade.

Finalmente temos as formulações que aproximaram o jusnaturalismo do direito natural, através do método: supunha-se a demonstrabilidade da ciência moral a partir do topos clássico, segundo o qual não é verossímil que o Criador tenha dotado os homens de faculdades suficientes para descobrir e demonstrar, com certeza, uma quantidade de coisas especulativas em especial, um grande número de verdades matemáticas - e não os tenha feito capazes de conhecer e de estabelecer, com a mesma evidência, as máximas da moral, sendo portanto a ciência moral suscetível de demonstração.

Logo, pode-se concluir que uma aspiração ao status científico, na perspectiva das ciências físicas, habita os tempos homéricos das ciências humanas.

O livro de Sokal possui uma particularidade que, a nosso ver, não está claramente destacada no texto que ora discutimos e é, entendemos, mais importante que qualquer discussão pontual: cobra a conta de algumas afirmações feitas por expoentes das ciências humanas, servindo-se de jargões das ciências físicas, procurando forjar uma precisão, e nesta perspectiva ressalta uma ruptura, pois ao contrário de seus "fundadores", o que se consegue com isso é, no máximo, uma mimetização do discurso do outro e não a tentativa de se chegar a um método equivalente em termos de rigor, alvo, sem dúvida, cercado com muitas escarpas escorregadias.

Registramos nossa satisfação em ler o texto que nos foi apresentado, especialmente pelo seu caráter instigante.

Para finalizar perguntamos quais serão os pontos de passagem possíveis para o desdobramento desta discussão? A nosso ver estará assinalado pelos avanços nas áreas da física, biologia e química, e a sua interação com os quatro pontos a seguir: revolução digital das telecomunicações, miniaturização acelerada da eletrônica, "comodificação" dos bites e domínio crescente do software sobre as formas materiais.

DICKENS, C., 1985. A Tale of Two Cities. London: Penguin Books. 


\section{Rita Barradas Barata}

Departamento de Medicina Social, Faculdade de Ciências Médicas, Santa Casa de São Paulo
$\mathrm{O}$ artigo A extensão da impostura de Ana Maria Aleksandrowicz traz à discussão a sempre renovada polêmica entre ciências naturais e as humanidades, recentemente atualizada pela paródia de Sokal. A autora, entretanto, pretende enfocar a velha polêmica articulando-a à questão da interdisciplinaridade e da filosofia da ação, visando suas aplicações no campo da Saúde Pública. O texto está organizado em três partes e pretendo apresentar meus comentários em relação a cada uma delas.

Quanto às "Imposturas Intelectuais", a autora parece privilegiar, em sua análise, a questão da recusa implícita à interdisciplinaridade que haveria na posição de Sokal \& Bricmont, na medida em que estes autores criticam qualquer forma de cooperação ou interação entre ciências naturais e ciências humanas ou sociais. Certamente, esta é uma leitura possível da crítica desses autores; entretanto, pareceme que o foco da discussão está mais na negação de uma filosofia ou sociologia da ciência feita por historiadores, sociólogos e filósofos que não são cientistas e, portanto, teriam sua produção interditada pela incapacidade de conhecer realmente os processos e procedimentos dos cientistas.

Creio que o núcleo duro da crítica às posições de Sokal \& Bricmont residiria em três pontos principais com implicações para a questão de interesse, ou seja, a interdisciplinaridade: a) os autores partilham uma teoria da ciência que poderia ser classificada como nä̈ve (o que os mesmos jamais aceitariam, visto tratar-se da aplicação de uma categoria estética a uma formulação teórica de outro campo) calcada no realismo ingênuo; b) uma certa confusão entre Ciência e Filosofia, uma vez que os autores pretendem aplicar, ao pensamento filosófico, os mesmos critérios de demarcação aplicáveis ao pensamento científico; c) os autores não distinguem entre o conteúdo conceitual dos conceitos científicos e sua significação hermenêutica apontada pelas críticas históricas, sociológicas e filosóficas.

Entretanto, como bem salienta a autora, há uma série de aspectos pertinentes na crítica de Sokal \& Bricmont. Aos aspectos apontados no artigo, eu acrescentaria a insistência dos autores no "recurso aos fatos", que poderia ser mais adequadamente traduzido pelo movimento dialético do trânsito entre concreto-abstrato e concreto pensado (Fernandes, 1980), como recurso de adequação entre teoria e mundo real, e a principal defesa face aos abusos identificados pelos autores na produção de importantes in- telectuais europeus e norte-americanos, extensivamente classificados como pós-modernos.

No que concerne à "Guerra das Ciências", Gould (2000) apresenta posicionamento semelhante ao do presente artigo, considerando que a oposição entre realistas e relativistas é mais uma falsa questão produzida em parte por nossa tendência em formular modelos dicotômicos. Para ele, a maioria dos cientistas, embora sendo nä̈ves com relação à história das ciências, são incapazes de ver o contexto social como inteiramente irrelevante da mesma forma que nenhum cientista social é completamente relativista.

No interesse da questão da transdiciplinaridade e da intersetorialidade talvez a pergunta a ser respondida seja: Por quê a Filosofia precisa se travestir de Ciência? Quais são os processos sócio-históricos que levaram intelectuais prestigiados a recorrerem à linguagem das ciências naturais em campos tão distintos quanto a crítica literária e a psicanálise? Esta démarche realmente propicia a inter/transdisciplinaridade?

Finalmente, a última questão tratada pela autora remete à relação entre pensamento e ação. A autora aponta o pragmatismo como uma solução para a superação da falsa oposição empirismo/racionalismo e para uma filosofia da ação, isto é, comprometida com a intervenção na realidade concreta. Estas características, entretanto, não são exclusivas do pragmatismo, estando mais ou menos presentes em todas as correntes filosóficas pós-kantianas. Praticamente, toda a teoria do conhecimento produzida nos séculos XIX e XX busca superar, através de diferentes formulações e com diferentes ênfases, as falsas dicotomias entre empirismo/racionalismo, indução/dedução, sujeito/objeto etc. O compromisso explícito com a práxis sofre maior modulação, permitindo identificar, segundo Samaja (1993), alguns conjuntos de escolas.

Sendo assim, e entendendo que a terceira parte representa a confluência da discussão anterior em direção ao campo da Saúde Pública, haveria necessidade de aprofundar a argumentação, no sentido de tornar mais explícita a possível contribuição da perspectiva pragmática. Há no texto algumas idéias bastante interessantes acerca da oposição possibilidade/potencialidade que estão apenas esboçadas, necessitando maior desenvolvimento. Ou será que, mais uma vez, estamos nos deixando levar pela irresistível atração da dualidade?

FERNANDES, F., 1980. Fundamentos Empíricos da Explicação Sociológica. São Paulo: T. A. Queiroz. 
GOULD, S. J., 2000. Deconstructing the "science wars" by reconstructing an old mold. Science, 287:253-261.

SAMAJA, J., 1993. Epistemología y Metodología. Elementos para una Teoría de la Investigación Científica. Buenos Aires: EUDEBA.

\section{Kenneth Rochel de Camargo Jr.}

Instituto de Medicina Social, Universidade do Estado do Rio de Janeiro
Ao iniciar meu comentário sobre o artigo proposto pelos editores de Cadernos de Saúde Pública para um debate, parto da constatação de que o tema é complexo e extenso para justificar minha opção de centrar minha intervenção no exame de um aspecto, qual seja, o da possível contribuição de Sokal \& Bricmont para discussões no âmbito da Saúde Coletiva.

Escolhi este tema por conta de minha reação inicial, de absoluta perplexidade, ao receber o texto em questão, que propõe ser possível uma leitura destes autores que permitiria “(...) focar alguns aspectos de sua proposta de interesse para a Saúde Pública” (p. 3). Meu estado inicial de perplexidade manteve-se após seguidas leituras tanto do texto quanto do livro em questão, em particular, por afirmar a autora que uma das críticas pertinentes de Sokal \& Bricmont seria destinada ao "(...) relativismo epistêmico/cognitivo (oriundo da filosofia e sociologia), especificamente a idéia de que a moderna ciência não é mais que um 'mito', uma 'narração', uma 'construção social', entre muitos outros (...)" (p. 4), e mais ainda, que os mesmos estariam de alguma forma abordando a interrelação entre disciplinas (p. 4).

Faço uma leitura radicalmente diferente daquela que a autora propõe, a qual passo a comentar a seguir.

Em primeiro lugar, gostaria de discutir o que a autora supõe ser uma crítica válida, àquilo que chamam, ela, Sokal \& Bricmont, de "relativismo epistêmico/cognitivo". A posição destes autores está expressa no capítulo 3 de seu livro. Ali verifica-se que, sob essa rubrica, os autores pretendem livrar a História e a Filosofia das Ciências de qualquer pretensão de questionamento do produto das últimas, a começar por Hume e passando por Quine, Popper e Kuhn até chegar ao grupo que denomina "pós-modernos”. Não seria possível examinar em detalhe este capítulo no espaço de que disponho aqui; limitar-me-ei portanto a algumas considerações de ordem geral. Em primeiro lugar, uma série de afirmações de Sokal \& Bricmont permitem identificar seu claro comprometimento com uma forma radical de realismo objetivista (apesar de algumas afirmações contraditórias), como, por exemplo, ao criticar Latour por deslizar “(...) da 'representação da natureza' na primeira metade da frase para 'natureza' tout court na segunda metade". Isto se repete em um comentário sobre um livro de Fourez, quando dizem que "O texto confunde fatos com afirmação de fatos”. Ora, a posição dos autores corresponde a uma dada corrente filosóficoepistemológica, mas será que simplesmente afirmá-la como tal automaticamente invalida qualquer interpretação filosófica diferente, como, por exemplo, a do neopragmatismo? Gostaria de colocar como contra-exemplo desta concepção um autor como Ludwik Fleck (1979), cujo trabalho, a começar pelo próprio título de seu livro Gênese e desenvolvimento de um fato científico, argumenta de modo convincente contra a distinção radical entre "fatos" e "afirmação de fatos”. Ou ainda, o conceito Bachelardiano de fenomenotécnica (Bachelard, 1971) também apontaria, a meu ver, para a ingenuidade desta distinção, na medida em que os "fatos" da ciência são cada vez mais os "fenômenos" produzidos em laboratórios, que só se tornam inteligíveis a partir de sua localização em uma complexa rede de teorias e procedimentos técnicos.

O mesmo tipo de equívoco surge nos comentários sobre Kuhn, como se vê, por exemplo, na afirmação de que “(...) as mudanças de paradigma, pelo menos na maioria dos casos desde o advento da moderna ciência, não ocorreram por razões totalmente irracionais". Ora, parece-me que a démarche de Kuhn vai em direção totalmente oposta, a de afirmar que estas mudanças não são totalmente racionais, mas a forma como esta idéia é exposta é característica persistente na discussão de Sokal \& Bricmont neste capítulo: a construção de posição caricata para os adversários de suas idéias, que pode então facilmente ser desmontada.

Mas adiante, neste capítulo, as dificuldades criadas tanto pelo realismo de Sokal \& Bricmont quanto pela sua estratégia de construção de ogros a partir dos moinhos de vento dos textos alheios, fica nítida quando tenta descartar aquilo que chamam de "versão radical da história da ciência de Kuhn", pois esta seria "autorefutável”. Segundo sua argumentação, como a história coleta dados de forma pelo menos análoga aos métodos empregados nas ciências naturais, se estas últimas não dispõem de um referente fixo, tampouco o terá a primeira, e Kuhn serrou o galho onde sentava. Novamente, isto só será um problema se se persiste em uma 
visão objetivista, representacional, do que seja fazer ciência. Se, ao contrário, assumirmos que fazemos um conjunto de asserções que em determinado momento nos parecem razoáveis, à luz do que reconhecemos como evidências empíricas e teóricas aceitáveis, tanto a história de Kuhn quanto a física de Sokal \& Bricmont podem repousar confortavelmente sobre afirmações provisoriamente aceitas como verdadeiras (como exemplo de perspectiva reflexiva que incorpora as contribuições de Kuhn, ver Epstein, 1988).

Ao contrário da autora do artigo, portanto, não vejo pertinência na crítica sokal-bricmontiana ao que estes denominam relativismo, nem vejo neste o risco que os mesmos apontam, em outro equívoco, de que a crítica a uma visão fundacionista da ciência conduziria a uma “apatia teórica” (posso pragmaticamente optar por determinado curso de ação, por julgá-lo mais convincentemente demonstrado, mesmo sem ter que necessariamente assumir que o mesmo é representação acabada do real, tal como verdadeiramente é); parece-me inversamente que o risco de colocar as produções da ciência além de qualquer crítica (e não alimentemos ilusões; é disto que se trata) é potencialmente muito mais perigoso, em especial na área de Saúde Coletiva, na medida em que sanciona intervenções sociais com base em pressupostos fundamentados pela ciência. Veja-se, por exemplo, quanto tempo foi perdido na implementação de medidas eficazes de combate à epidemia de HIV/AIDS por conta da associação feita, de modo excludente, com o homossexualismo masculino ou, ainda, do quanto este último tem sido discriminado também com base em asserções pretensamente "científicas".

Mas a maior dificuldade que tenho em considerar a possibilidade de recolher qualquer contribuição da extensa diatribe desses autores reside na ambigüidade com que caracterizam suas intenções, dedicando-se mais a falar do que não pretendem. Por exemplo, após apresentar a genealogia do texto que produziram, na página 10 do seu livro colocam-se a pergunta: "Mas o que pretendemos exatamente? Nem oito nem oitenta." Depois de atacar um conjunto de autores de língua francesa, terminam dizendo que "Não pretendemos dizer que isto invalida o restante de sua obra, sobre a qual não emitimos julgamento", embora mais a frente esclareçam que "[p]orém, quando a desonestidade intelectual (ou flagrante incompetência) é descoberta num trecho - mesmo marginal - do texto de alguém, é natural querer examinar mais criticamente o restante de seu trabalho. Não queremos prejulgar os resultados de tal análise, mas simplesmente remover a aura de profundidade que por vezes impediu estudantes (e professores) de empreendê-la" (p. 21). Ou seja, ainda que obliquamente, há sim, de fato, o julgamento depreciativo que o tempo todo afirmam não fazer

Voltando ao prefácio, mais adiante, declaram: "Temos objetivos mais amplos em mente, mas não necessariamente aqueles a nós atribuídos" (p. 11), e prosseguem sem esclarecer efetivamente que objetivos grandiosos seriam esses. A definição mais clara surge já no final do livro, em um dos apêndices, de autoria apenas de Sokal, quando este declara explicitamente que "[a]ntes, meu interesse é explicitamente político: combater o discurso pós-modernista/pósestruturalista/social-construtivista atualmente em moda - e mais genericamente a tendência para o subjetivismo - que é, acredito, prejudicial para os valores e futuro da esquerda" (p. 287).

Trata-se portanto de uma luta política, onde Sokal lançou mão de atos eticamente discutíveis, como submeter uma paródia, como se fosse um artigo, a determinada revista, e neste sentido não penso, como a autora do artigo, que se deva "propor algo em troca", na medida em que Sokal \& Bricmont não parecem, eles mesmos, interessados em um diálogo. Por este mesmo motivo, não acredito que haja nestes autores quaisquer lições a extrair sobre multi, inter, trans ou pluridisciplinariedade. Citando Foucault, um dos autores, aliás, criticados de modo particularmente superficial por Sokal \& Bricmont: "No intercâmbio sério de perguntas e respostas, no trabalho de elucidação recíproca, os direitos de cada pessoa são de algum modo imanentes a discussão. Derivam da situação de diálogo. (...) Perguntas e respostas dependem de um jogo, um jogo que é ao mesmo tempo prazeroso e difícil, no qual cada um dos dois parceiros se compromete a só usar os direitos que lhe são dados pelo outro e pela aceitação da forma de diálogo. O polemista procede baseado nos privilégios que tem de antemão e nunca vai questionar. (...) O polemista assume uma legitimidade que por definição é negada a seu adversário" (Rabinow, 1999:17-18).

Do ponto de vista político, por fim, prefiro acompanhar uma lição de Pierre Thuillier, que afirmou que "[s]e ensinarmos as pessoas a respeitar demais a ciência, estaremos minando sua possibilidade de criticar a tecnocracia" (Thuillier, 1989:23).

BACHELARD, G., 1971. A Epistemologia. Lisboa: Edições 70.

EPSTEIN, I., 1988. Revoluções Científicas. São Paulo: Editora Ática. 
FLECK, L., 1979. Genesis and Development of a Scientific Fact. Chicago: University of Chicago Press.

RABINOW, P., 1999. Antropologia da Razão. Rio de Janeiro: Relume-Dumará.

SOKAL, A. \& BRICMONT, J., 1999. Imposturas Intelectuais. Rio de Janeiro: Editora Record.

THUILLIER, P., 1989. Entrevista. Ciência Hoje, 9:18-23.

\section{Carlos Alberto \\ Gomes dos Santos}

Departamento de Filosofia, Pontificia Universidade Católica do Rio de Janeiro c.santos@mail.rdc. puc-rio.br
O artigo de Ana Maria Aleksandrowicz levanta questões muito importantes para a Filosofia da Ciência contemporânea, indo além dos interesses meramente acadêmicos para inserir-se no âmbito prático, com implicações significativas para o desenvolvimento de projetos de pesquisa e a implementação de programas voltados para o social, inclusive na área das políticas governamentais. Nesse sentido, atribuo um grande valor a este trabalho de cunho eminentemente filosófico, levado a cabo por uma convicção com a qual compartilho: a de que o debate das idéias não está necessariamente, por sua natureza especulativa, descompromissado com a prática. Os grandes filósofos procuraram não apenas compreender os problemas de sua época, mas também contribuir para a sua solução. Como disse Aristóteles (The Loeb Classical Library, 1992) na Ética a Eudemo, não devemos pensar que é supérfluo, para uma pessoa dedicada à política, engajar-se em uma reflexão que a faz perspicaz não somente a respeito do "quê", mas também do "porquê"; essa é, para ele, a contribuição do filósofo em qualquer área.

Segundo Karl Popper (1967), a Teoria do Conhecimento ou Epistemologia, considerada uma das disciplinas filosóficas mais afastadas dos problemas da vida cotidiana, tem conseqüências decisivas na ética e na política, fundamentando e justificando, conforme os pontos de vista assumidos, quer regimes totalitários ou, ao contrário, práticas democráticas.

Em seu trabalho, Ana Maria aborda temas fundamentais da Epistemologia: as diversas abordagens epistemológicas, como as fundacionistas (racionalistas ou positivistas), e as relativistas ou irracionalistas, que negam a existência de fundamentos seguros para a constituição da Ciência; o problema da demarcação entre Ciência e pseudo-ciência; a natureza do saber científico; a especificidade ou não das Ciências Humanas; a interdisciplinaridade; o poder de intervenção efetiva das Humanidades na realidade; a relação teoria e prática; a ques- tão da transgressão de fronteiras e competências. Esses temas são tratados com a preocupação de resgatar a confiabilidade das Ciências Humanas e a importância da discussão sobre Fundamentos, ressaltando a necessidade de abordagem interdisciplinar das questões relativas a projetos de pesquisa e a programas de ação em saúde pública.

É no mínimo curioso que ainda tenhamos a necessidade de demonstrar a importância dos saberes constituídos através de procedimentos que não se adaptam aos cânones metodológicos do saber científico, o qual encontra, na Física de Galileu, Descartes e Newton, seus fundamentos e sua expressão maior. Esse saber se impôs pelos seus resultados, e seu êxito é justificado pelo método que lhe garante a objetividade, a racionalidade, sua força preditiva e, conseqüentemente, seu progressivo poder de intervenção sobre o real.

Filósofos neopositivistas do chamado Círculo de Viena propuseram a verificabilidade empírica como critério de demarcação entre as proposições dotadas de sentido (as legítimas, verificáveis empiricamente) e as pseudo-proposições (que, embora construídas de acordo com as regras da sintaxe e da gramática, são desprovidas de sentido), identificando as primeiras com as proposições científicas, e as segundas com as metafísicas.

A afirmação de John Brockman, citada no artigo de Ana Maria, reflete bem a crença sustentada desde o século XVIII, de que enfim chegara, com a superação das superstições e da metafísica, o tempo das verdades justificadas racional e experimentalmente que garantiriam a igualdade, a fraternidade, o progresso humano e social. Ora, esta visão otimista e até mesmo messiânica da Ciência Moderna, assentada no racionalismo cartesiano e no método analítico experimental hipotético-dedutivo da física newtoniana, é que vem sofrendo reparações críticas por parte de muitos filósofos. Passados quase quatrocentos anos da fundação da Ciência Moderna, vemos que mais de dois terços da população mundial não tem acesso nem a este conhecimento nem aos benefícios que ele pode trazer.

Não se trata aqui de negar o valor da ciência, mas sim determinada maneira de compreendê-la e avaliá-la. Considero da maior importância estarmos atentos para submeter à crítica os aspectos ideológicos que sustentam não só a hegemonia do saber científico como a desconsideração do valor das demais vias humanas de acesso para a compreensão e conseqüente intervenção no real. Não pretendo defender o relativismo epistemológico, mas reco- 
nhecer a sua contribuição para o debate contemporâneo em Filosofia da Ciência. A relevância dos pensadores desta corrente está manifestada na imensa bibliografia que, após a década de 50, vem enriquecendo a discussão filosófica sobre o conhecimento científico.

Reconhecer que parte da produção intelectual da área das Humanidades se perdeu em questões de minúcias tão afastadas da prática, em um preciosismo da linguagem acadêmica ininteligível aos não especialistas, não implica aceitar a tese de Brockman de que as únicas idéias dignas de serem postas em circulação são as da comunidade científica. As grandes narrativas não podem ser desprezadas: elas agem sobre os indivíduos e sobre as relações sociais; elas nos dirigem para os fundamentos das nossas experiências, conferem sentido e compreensão do mundo e dos sujeitos que nele habitam. E, se com nossos projetos buscamos mudanças de atitudes e de comportamentos, não podemos nos esquecer de que não há argumento racional, nem evidência qualquer que por si sós sejam capazes de fazê-lo.

Estas considerações nos levam à temática da interdisciplinaridade, ou seja, da colaboração entre ciências naturais e ciências humanas, tão bem expressa no texto de Ana Maria, como abordagem imprescindível aos "novos paradigmas de Saúde Pública”. Como a motivação do artigo foram as idéias de Sokal \& Bricmont, vale traçar alguns comentários a respeito.

Se, para uma interpretação benévola, a paródia de Sokal teve o propósito de chamar a atenção para a necessidade de recuperar o prestígio da Filosofia e das Ciências Humanas com uma crítica ao intelectualismo vazio que, segundo ele, delas teria se apossado, devo dizer que discordo inteiramente da estratégia que utilizou. A sua presença sensacionalista na mídia restringiu-se quase que exclusivamente aos seus dois primeiros artigos, nos quais lançava profundas desconfianças sobre o pensamento de autores de reconhecida notoriedade, sobretudo no campo da Filosofia. O fato da mídia não ter acompanhado com a mesma intensidade o debate que se seguiu, certamente acabou ampliando o descrédito para com a significação e o alcance social das Humanidades junto à opinião pública semi-erudita.

Sokal fala de "transgressão de fronteiras" por parte de estudiosos das Humanidades quando os acusa de cometerem a impostura de utilizar erroneamente conceitos da ciência com o fim de sustentar suas posições teóricas e conferirlhes a credibilidade científica que, de outra forma, não teriam. Em realidade, Sokal se refere, em especial, aos críticos do cientificismo e, sem a menor parcimônia, reúne em etiquetas generalizadoras de "pós-modernos" e "relativistas" autores que tenho certeza que nelas não se reconheceriam, como Deleuze, Lyotard, Baudrillard, Jameson, Quine, Kuhn, Feyerabend, entre outros.

Não foi preciso que Sokal o dissesse para que reconhecêssemos que filósofos e cientistas sociais cometeram e cometem erros e impropriedades na compreensão e até mesmo na utilização de conceitos científicos; mas, a meu ver, estes equívocos só invalidariam o pensamento destes autores se a força de seus argumentos neles se baseasse. Avaliar o conteúdo das proposições científicas é tarefa do físico; ao filósofo cabe analisar os critérios de avaliação e de justificação através da explicitação e análise de seus pressupostos. Para submeter à crítica o raciocínio indutivo, o papel da experiência na validação das hipóteses, os limites e o alcance cognitivo das teorias e leis científicas, o papel da linguagem na construção do real, a existência ou não de puros dados de observação, não é preciso ser físico nem ter conhecimento técnico das teorias científicas.

É, no mínimo, ingênuo o pensamento de Sokal de que a credibilidade do conhecimento científico, o status privilegiado de que goza na nossa sociedade se devem apenas ao valor intrínseco de seu método. Reconhecer a influência do contexto histórico-social na construção, no desenvolvimento e na aceitação da ciência não significa necessariamente cair no relativismo epistêmico. Vale também notar que o capítulo III do livro de Sokal \& Bricmont, dedicado à reflexão epistemológica, poderia muito bem servir de exemplo de transgressão de fronteiras no sentido de Sokal. Não é preciso ser especialista em Epistemologia para descobrir os equívocos e as ambigüidades que vão se sucedendo no texto. É espantosa a maneira com que Sokal aborda o problema da indução e a crítica que dirige a Karl Popper. Para ele, utilizar ou não a indução, afirmar se o raciocínio indutivo se justifica, vai depender do caso em questão: algumas induções são mais razoáveis e outras menos. Ora parece tender estranhamente para a defesa de um relativismo epistemológico que condena em Feyerabend, ora se inclina para uma espécie de pragmatismo que nos faz lembrar Larry Laudan, aliás citado quatro vezes no texto de Sokal \& Bricmont. Mas o pragmatismo com suporte realista de Sokal em nada se aproxima das cuidadosas e sérias reflexões de Laudan na defesa de determinado pragmatismo expressas em suas obras.

De qualquer forma, não penso que o diálogo necessário entre as Ciências Humanas e as 
Ciências Naturais seja implementado por esta forma de polêmica provocada por Sokal \& Bricmont. As fronteiras precisam ser transgredidas, superando as barreiras erguidas pelos olhares parciais, limitadores, autoritários. É fácil afirmar que queremos conhecer o todo para melhor agirmos sobre as partes; não é fácil, porém, admitir que só poderemos percebê-lo com o concurso de olhares diversos.

POPPER, K., 1967. Sobre las fuentes del conocimiento y de la ignorancia. In: El Desarrolo del Conocimiento Científico - Conjeturas y Refutaciones (N. Míguez, org.), pp. 9-16, Buenos Aires: Paidos.

THE LOEB CLASSICAL LIBRARY., 1992. Aristotele, v. XX. London: Harvard University Press.

\section{Ubiratan D'Ambrosio}

Universidade Estadual de Campinas
Muito oportuna a discussão sobre o importante conflito que vem sendo focalizado nos últimos anos por importantes setores da vida acadêmica. As partes envolvidas vão se polarizando em ataques e defesas que - muitas vezes carregados de conotações corporativistas - têm tido como efeito uma intimidação à crítica salutar e necessária para se fazer avançar o conjunto de explicações próprios de uma civilização. Aleksandrowicz faz uma revisão parcial da literatura recente sobre o que vem sendo chamado a "Guerra das Ciências", uma extensão óbvia do que C. P. Snow denominou, há quase quarenta anos, as "Duas Culturas”. A discussão não pode deixar de considerar aspectos históricos e geopolíticos.

A história nos mostra que tais conflitos acompanham a evolução do conhecimento. Particularmente, na cultura ocidental, o conhecimento desenvolvido nas academias (héka = distante + demos $=$ povo) e no isolamento dos mosteiros é assimilado pela população em geral, tornando-se parte do cotidiano e alterando comportamentos.

Comportamento e conhecimento estão intimamente associados, em uma relação que poderíamos chamar simbiótica. São a resposta às pulsões de sobrevivência e de transcendência que distinguem a espécie humana e que dão origem a sistemas de explicações e maneiras de lidar com o cotidiano, organizadas como mitos, tradições, artes e tecnologias, e ciências. Todas as respostas às pulsões de sobrevivência e de transcendência originam-se e se organizam em determinado ambiente espacial e tem- poral. Em outros tempos e em outras regiões, as respostas são obviamente distintas. Um processo de dinâmica cultural que se dá nos encontros de indivíduos com outros, de comunidades com outras, de povos com outros, é responsável pelas transformações dessas respostas. Essas transformações ocorrem lentamente e estão incorporadas à história de cada indivíduo, da comunidade e do povo, como discuto amplamente no meu livro Etnomatemática (D’Ambrosio, 1990). Nesse livro, tomo, como foco das minhas reflexões, o conhecimento matemático, que é central na civilização moderna. É interessante notar que um argumento importante de Sokal \& Bricmont é a apropriação de linguagem e resultados da matemática pelos intelectuais que são alvo dos ataques. Recentemente, Sokal (1999) retoma a centralidade do conhecimento matemático na sociedade moderna em editorial pago, no qual ataca programas inovadores de educação matemática nos Estados Unidos.

A partir das grandes navegações, caminhase para uma civilização planetária. Por um lado, a cultura ocidental, levada pelos conquistadores e colonizadores a todo planeta, perturbou os princípios básicos da dinâmica cultural, dando origem aos culturalmente excluídos e subordinados. Por outro lado, a reorganização política e econômica, que veio com o fim do regime colonial, abalou a hegemonia dos sistemas de explicações e de maneiras de lidar com o cotidiano, organizadas como mitos, tradições, artes e tecnologias, e ciências. São freqüentemente notadas e denunciadas as inadequações do sistema hegemônico nas áreas da política, da economia, das religiões, da saúde, da agricultura, da tecnologia e das ciências em geral. As diferentes culturas, há tantos anos reprimidas e subordinadas, começam a manifestar-se. A chamada pós-modernidade - no meu entender, uma denominação muito infeliz - é uma forma de reação à hegemonia associada à modernidade. "A transdisciplinaridade repousa sobre uma atitude aberta, de respeito mútuo e mesmo de humildade com relação a mitos, religiões e sistemas de explicações e de conhecimentos, rejeitando qualquer tipo de arrogância ou prepotência. A transdisciplinaridade é transcultural na sua essência" (D’Ambrosio, 1997: 80). A defesa de posições hegemônicas, tais como os fundamentalismos, manifesta-se nas Ciências em uma forma de arrogância da academia tão bem notada na chamada "Guerra das Ciências".

D’AMBROSIO, U., 1990. Etnomatemática. São Paulo: Editora Ática. 
D'AMBROSIO, U., 1997. Transdisciplinaridade. São Paulo: Editora Palas Athena.

SOKAL, A., 1999. Open letter to the U. S. Secretary of Education Richard Riley. Washington Post, Washington, D.C., 18 nov.

\section{José Ricardo Ayres}

Departamento de Medicina, Faculdade de Medicina, Universidade de São Paulo
Quando se discute o affair Sokal-Bricmont, a tendência é a polarização a favor ou contra a estratégia ou o conteúdo da "denúncia" ali realizada. Em qualquer destas posições, não se vê senão a necessidade de atacar ou defender os modelos de conhecimento das Ciências ditas “duras" e/ou suas pretensões colonizadoras sobre qualquer área da experiência humana. Aleksandrowicz escapa a essa armadilha e, de forma deliciosamente surpreendente, brinda-nos com o improvável: a tese do "engajamento social" dos autores.

Surpreendente, sim, mas a tese é coerente e consistentemente defendida pela autora. Aleksandrowicz realiza sua "propedêutica" no exame da questão em perfeita harmonia com a "terapêutica" que prescreve em suas conclusões, qual seja, buscar o novo, resistir aos apelos da mera repetição. Alinhada à atitude pragmática de pensadores como James e Atlan, a autora defende uma concepção de conhecimento verdadeiro orientada por critérios positivos de eficácia prática, baseado na exploração de diferentes possibilidades, inclusive conflitantes, de expressar de modo socialmente válido uma experiência qualquer.

É essa busca de possíveis pragmaticamente explorados que leva Aleksandrowicz à sua "herética” tese do engajamento. Em termos sintéticos, a autora identifica em Sokal \& Bricmont - ainda que eles próprios não o formulem explicitamente - uma autêntica preocupação com o caráter inoperante do conhecimento nas ciências humanas. A autora mostra como a escolha dos textos criticados e das "imposturas" denunciadas têm como fundamento a carência de significado dessa produção teórica para o tipo de problemática que poderia interessar o conhecimento humanista, e engrossa o coro: as Ciências Humanas - as sociais, em particular - estariam paralisadas, buscando legitimarse, parasitando a autoridade das Ciências "Naturais" e abstendo-se de enfrentar os desafios práticos da mudança social. Falta-lhes a energia do desejo, a audácia da invenção, a coragem da contestação, sustenta.
A leitura que Alecsandrowicz faz de Sokal \& Bricmont apresenta, assim, a notável qualidade de retirar o debate do plano das infrutíferas animosidades - ainda que perfeitamente compreensíveis, dada a estratégia crítica, no mínimo deselegante, adotada por esses autores - ou dos anacrônicos e estéreis antagonismos entre ciências naturais e humanidades. Ao retomar a polêmica no patamar da operosidade prática das Ciências Sociais, Aleksandrovicz coloca-se em condição de efetuar uma crítica, a meu ver, muito mais rica de Sokal \& Bricmont. A autora desnuda o marcado didatismo destes autores e o correspondente messianismo com que atribuem às Ciências Naturais, e ao tipo de rigor científico lá desenvolvido, um papel redentor sobre todos os problemas tradicionalmente enfrentados pelas supostamente imaturas ciências humanas. Contrapõe-lhes, em troca, o pluralismo e interdiciplinaridade das propostas de Henri Atlan.

Aqui reside, em minha opinião, o ponto alto da sua discussão e, ao mesmo tempo, seu momento de menor coerência. Ponto alto porque permite aproveitar o convite à ação, implícito em Sokal \& Bricmont, sem precisar aceitar a contragosto uma terapêutica "naturalizante" para os problemas sociais e seu conhecimento. Contudo, não será contraditório com a inspiração pragmatista da autora sua proposição de um modelo atlaniano como o paradigma de um pensar simultaneamente rigoroso, criativo e adequado às Humanidades?

Não obstante simpatizar muito com o entusiasmo da autora pela obra de Atlan, impossível não contrastar o emblemático "horror" pragmatista aos universais com o tom prescritivo de Aleksandrowicz, ao introduzir a epistemologia atlaniana na discussão. Esse caráter prescritivo é já ensaiado no início do texto, quando a autora afirma não haver, hoje, pensador nas ciências humanas capaz de associar a especificidade do conhecimento na área social a conceitos positivos para a ação. Essa afirmação, além de não fazer justiça a nomes como Jürgen Habermas - só para ficar com um, que me é mais caro - transparece um tipo de exigência epistemológica que parece construirse à margem do campo a que se refere. Caricaturando, é como se autora afirmasse: "Os cientistas sociais não sabem fazer ciências sociais". Ora, não pressupõe tal posição algum critério externo à própria práxis desses cientistas, um critério a priori e universal, do que seja "verdadeiramente" fazer ciência social?

No mesmo sentido, essa epistemologia "ideal" vai se insinuar no final do texto, quando se associa, ainda que de forma subliminar, a "boa 
ciência” à solução encontrada por Atlan para uma "boa biologia”. Não que o pragmatismo interdite a possibilidade de discursos oriundos de campos diversos fecundarem-se mutuamente; ao contrário. Mas será compatível com o que Rorty (1996) chama de "textualismo forte", que se possa prescrever uma linguagem para um campo de conhecimento que não tenha surgido da própria experiência prática dos sujeitos que vêm construindo esse campo?

Deixo essas questões para a autora não como cobrança de coerência teórica, a qual, como exigência apenas formal, julgo totalmente estéril. A liberdade necessária ao conhecer, tão bem assinalada pela autora, precisa das rupturas heterodoxas. Se ressalto a "incoerência" do texto justamente quando mais o valorizo é porque gostaria de destacar um aspecto da atitude pragmática cuja discussão me parece ter um significado prático da maior relevância: precisamos aceitar junto com o vigoroso anti-fundacionalismo do pragmatismo seu horror pelos universais? Será mesmo preciso abandonar toda e qualquer pretensão de universalidade para preservar o caráter aberto e libertário da razão humana? O exercício de transposição da questão "possível/potencial” para a formulação epidemiológica do risco - infelizmente só esboçado no artigo - não será indício concreto de que há ali algum universal de interesse emancipatório em jogo? De minha parte, penso que a busca de certas universalidades pode ser, nas humanidades tanto quanto nas ciências naturais, um importante móvel utópico, no preciso sentido de um constructo humano; um potente, embora imperfeito, antídoto contra a barbárie; um dispositivo com o qual homens e mulheres vêm buscando construir sua liberdade ao longo da história. Quais universalidades aceitar, e em que circunstâncias, seguirá sempre sendo, porém, decisão a ser tomada, e em consenso, o que as torna ainda mais valiosas.

RORTY, R., 1996. Nineteenth-century idealism and twentieth-century textualism. In: Consequences of Pragmatism (Essays: 1972-1980) (R. Rorty, ed.), pp. 139-159, Minneapolis: University of Minnesota Press.

\section{O autor responde}

The author replies

Ana Maria C. Aleksandrowicz
“(A razão) pode acompanhar e ajudar, se o desejarmos, uma moral do diálogo e do encontro entre moralidades diferentes, civilizações diferentes. Caminhar progressivo, onde apenas se parte do particular em direção, sem garantia de êxito, a um universal que deixou de ser um dado adquirido à partida" (Atlan, 1991:13) (...) "E é (neste quadro) (...) que devemos, se assim o desejarmos, construir um universal pragmático (...) através de contratos entre nações, povos e sociedades, nos quais os indivíduos aprenderam, antes de mais, a falar suas línguas e a reconhecer-se" (Atlan, 1991:19-20).

Antes de mais nada, quero agradecer a oportunidade de estar, a partir das respostas inspiradas de vigorosos interlocutores, participando de um pulsante debate intelectual - ainda que por via escrita, donde de expressão intermitente -, uma das formas, a meu ver, de eleição para a (re)construção/vitalização do Conhecimento, por sua característica de entrecruzamento de múltiplos pontos de vista, os quais me cumpre, agora, recortar e aproximar da melhor maneira a valorizar tal fecundidade. Dada a restrição de espaço, precisei privilegiar, dentre o amplo alcance de cada comentário, uma sua dada vertente, a mais adequada a participar do desenvolvimento do debate nos termos que passarei a propor, inevitavelmente deixando em aberto questões pertinentes e instigantes, que, espero, possam ser proximamente retomadas. Procurei auxílio, nesta empreitada, em algumas das idéias de Henri Atlan, pelas quais norteio, pois, nosso rumo, aproveitando para divulgar e exercitar, neste ensejo, aplicando-o aos termos do presente debate, um dos eixos centrais de seu pensamento: a imprescindibilidade de um novo pensar, que leve em conta a atual renovação absoluta dos termos ("contagiados" por suas alterações / (re)invenções recentes, por exemplo, no campo da Saúde, as inerentes aos progressos das Biotecnociências) em que são colocados os (mesmos?) problemas, em especial quando são necessárias abordagens interdisciplinares.

\section{A intercrítica no espaço das fronteiras}

Atlan $(1994,1999)$ propugna pela separação entre as diferentes formas de racionalidade - a 
científica, a filosófica e a mítica - na atitude crítica a ser exercida quando da consideração de um problema, o que nos permite transplantar esta postura para os campos da Ciência e das Humanidades, uma vez que, aqui e ali, o que está em questão é a especificidade dos fundamentos oferecidos aos também diversos objetivos a serem alcançados. Embora tais objetivos possam convergir, no momento da prática, em termos de se complementarem para assim aumentar chances de eficácia, enquanto gênese-metodologias-finalidades são essencialmente incomensuráveis. É, aliás, justamente tal impossibilidade de tradução imediata que lhes faculta a mútua inseminação. Atlan credita grande importância a um espaço nas fronteiras (estabelecidas entre tais racionalidades) do Conhecimento, por onde se dá o trânsito a que chama "intercrítica": esta consiste em uma atividade de utilização das interfaces quais espelhos, que permitam a cada saber refletir sobre seus valiosos pontos duvidosos, reformulá-los, reapresentá-los, erigindo deliberadamente "barreiras" entre suas explicações, recriando-se e reconstituindo-se. Assim, pode ser, inclusive, mais funcional, se e quando solicitado a servir a decisões tomadas em comum com os outros saberes.

Trata-se, naturalmente, de um não-território de obrigatória tensão, em especial pela nossa incoercível tendência de reduzi-lo aos termos com que estamos familiarizados. É justamente esta tensão e os erros e correções que dela brotam que são criativos e imprescindíveis. O maior desafio aqui corresponde a uma postura (intelectual? emocional? humana?) de real interesse na compreensão - não assimilativa! - do Outro (indivíduo/grupo? discurso? saber/poder institucional?) ao qual são correlatos o prazer da diferença, a curiosidade respeitosa face tanto ao desconhecido como ao desagradável pelo reconhecimento, em ambos, de irredutíveis lacunas nossas. Repito: só esta atitude, ao contrário do que parece, é operacional pelo tipo de discordâncias/alianças férteis que promove.

As observações da grande maioria de meus interlocutores parecem-me estar em sintonia com o cerne da intercrítica atlaniana, que eu apenas delineara. Acredito ser evidente a inferência do quanto uma oposição-aceitação incontestes - já que a aderência anula o espaço para o trânsito - à parcialidade de Sokal \& Bricmont (a ser, ao invés, dinamizada para seu melhor aproveitamento possível ) seria, por definição, estranha ao exercício intercrítico do pensar.

Gostaria de iniciar, apreciando a notável afinidade dos comentários da cientista social Minayo - e do cientista natural - Domingues. Falando de um mesmo lugar inter-fronteiras, o das "condições do diálogo", é a crítica às "arrogâncias" que o estorvam que dá a tônica aos dois discursos. Em uma espontânea porém exímia convergência de estilo-conteúdo - o que, a meu ver, é a característica da boa retórica (em prol aqui de melhor causa) - de forma límpida e despretensiosa, os dois autores descortinam temas cruciais, dos quais destaco dois.

O primeiro modula-se sobre a análise da falta de conhecimento e mais do que isto, do reconhecimento desta ignorância, entre os diferentes campos do saber, que quando "se desconhecem, se estranham e se utilizam de forma banalizada" (Minayo), originando a "lamentável situação de achar que se discorda - ou concorda - com o interlocutor quando sequer houve comunicação" (Domingues). Ambos apontam para o emprego apressado de termos tornados exclusivos de determinada área, por derivação dos "hábitos de olhar" de seus usuários "oficiais", em contextos a eles alheios, tanto entre especialistas de áreas afins (Minayo), quanto por parte daqueles que pretendem difundir sua mensagem/ linguagem para o público leigo (Domingues). Assim, estabelecem os fundamentos de uma crítica sutil e penetrante aos vícios da banalização dos olhares, em consonância com a perspectiva atlaniana que vê, no mecanismo da trivialização, o grande empecilho à complexidade geradora de idéias e ações em uma sociedade.

Em um segundo momento, associam-no ao fato de que "uma linguagem para ser reconhecida deve ser (...) instituída por uma comunidade que a controla e administra produções e mudanças" (Minayo), ao que Domingues adiciona que estamos lidando com escolas de pensamento quais de iniciados, com histórias, culturas e tradições complexas, passíveis de serem protegidas como "bens preciosos". Os dois autores, corajosamente, insistem nos viscerais “assuntos tão pouco científicos” que Minayo descreve como "relacionados ao poder, à concorrência e à legitimação, que provocariam a ostentação e erudição superficial" e Domingues como a defesa de "interesses paroquiais(...) prestígio junto aos pares” etc. Enquanto Minayo desvela "os intelectuais imbecis, inclusive diplomados", Domingues declara legítimo o debate entre um espírita e um psicólogo, validando (a la Atlan) as diferentes racionalidades.

O que está em questão é a responsabilidade - pouquíssimo levada a sério e citada de passagem "para não perder tempo" em nosso meio - da atitude acadêmica que desvirtua o alcance de suas próprias leituras, por assimilálas apenas o suficiente para "embasar" partidarismos e/ou vaidades e, desta forma, alija do 
convívio das idéias as inteligências inexpertas (ingênuas ou "desatualizadas") que conformam um público potencial negligenciado. Aliam-se, assim, por inércia ou preconceito, às "manipulações econômico-culturais" e às estratégias "brockmanianas”. A intercrítica atlaniana não tem, pois, somente dimensão intelectual, mas social, educacional e democrática.

Deslocando-nos para o prisma mais estrito dos estudos sociais, a contingência da tensão que subjaz tanto à (re) estruturação constante das sociedades quanto às oscilações entre os limites das disciplinas que sistematizam a sua decodificação é postulada por Najar como correspondente "(à) dicotomia de nossa coalizão civilizatória”, em função da qual “(o) que se esclarece encontra-se mais nos argumentos periféricos do que nos principais". Gomes prossegue a discussão, assinalando a necessidade das lutas e alianças como constitutivas da humanidade (em todas as organizações sociais) e do pensamento, por promover questionamentos mútuos e novas soluções "reformuladas processualmente". Voltando a Sokal \& Bricmont, Najar ecoa Atlan, quando diz que "talvez as duas culturas sejam mundos possíveis, mas diferentes (e...) se compreendidos como tal resolvesse o lado estéril e histriônico do debate". Concordo plenamente com meus dois debatedores. Sugiro, nesta mesma direção, a apurada releitura weberiana feita por Diggins (1996), a qual surpreende, naquele autor clássico, nuances muito coincidentes com o novo pensar atlaniano. Diggins acentua o que chama "sensibilidade dualística" de Weber, que lhe permitiria "discernir desarmonia e conflito, e resistir à tendência tão marcante na tradição alemã (...) de ver a história como a superação de tensões e antagonismos, movendo-se a sínteses cada vez mais novas e elevadas" (Diggins, 1996:179).

Quanto à ambigüidade no uso que faço dos termos Ciências Humanas (?) /Humanidades (?) - acuradamente apreendida por Gomes - esta deve-se a certa "flutuação conceitual" que assumi deliberadamente, por não ter elaborado o suficiente (a partir, inclusive, de minha releitura atlaniana) quais os estatutos da Ética e da Filosofia (em suas concepções maiúsculas e/ou minúsculas) em relação àquelas classificações. Faço minhas as dúvidas de Barata com referência ao lugar da Filosofia - na excelente metáfora da debatedora, passível de ser "travestida" em ciência - nesta “catalogação”. Em relação ao texto desta autora, que, parece-me, situa suas observações bem no âmago do espaço intercrítico, simpatizo, particularmente, com o posicionamento de Gould citado. Atlan também é bastante sagaz quanto às "falsas questões" que lentificam o pensar produtivo. Por exemplo, acerca da oposição monismo/dualismo filosófico (muito em voga nas filigranas do problema corpo-mente), para Atlan (1994), tratar-se-iam de duas experiências distintas do observador que as alterna - dependentes da permanente dinâmica de sua relação com a aproximação/afastamento perceptivos $\mathrm{d}$ (entre)/a(s) realidade(s) a ser(em) descrita(s) como matéria-espírito.

\section{"A ética vem de outro lado"}

Para Atlan, a ética diz respeito à racionalidade mítica - termo de acepção muito particular, neste autor, que abrange, por exemplo, o mito, a arte, expressões do Inconsciente individual e de grupo, a mística e certos aspectos de metafísica -, distinguindo-se das racionalidades tanto filosófica (não obstante o esforço de inumeráveis filósofos para fundamentá-la por esta via) quanto científica. Exprime-se, primeiro, na existência dos homens, vem "de outro lado", pois "diz respeito a um projeto, a um querer, muito mais do que ao conhecimento (...) só podendo ser o objeto de uma reflexão (...) depois de ter-se imposto como conjunto de regras $e$ comportamentos vividos" (Atlan, 1994:228).

Este estatuto especial que Atlan confere à ética, propicia à dinâmica intercrítica um alcance surpreendente, pois oferece uma perspectiva inusitada - e, a nosso ver, oportuníssima - no estabelecimento de fronteiras entre as atribuições das diferentes racionalidades. Utilizaremos esta tênue e firme linha de demarcação para, por ela, cotejarmos as posições - da forma pela qual as relemos - de alguns de nossos mais incitantes debatedores.

Podemos observar a repercussão dos diversos entendimentos do papel da Ética em relação à atribuição da utilidade da Filosofia para a Saúde Pública, através das diferenças sutilíssimas - em relação a suas contundentes semelhanças (de acordo também com Atlan, que propugna pelo diálogo através dos contrastes) - entre os comentários de Camargo e Santos. Diga-se, de passagem, que sinto-me à vontade face ao apaixonado, ardente repúdio de ambos às "picaretices" de Sokal \& Bricmont no terceiro capítulo das Imposturas; logo no meu 3o parágrafo, assinalo a banalização de suas discussões sobre Epistemologia e superficialidade de sua crítica ao pós-modernismo. Entretanto, o ponto intrigante que desejo pinçar é porque Santos percebe na discussão que apresento suficiente valor por "seu cunho eminentemente filosófico (...) para o desenvolvimento de projetos de pesquisas e a implementação de programas voltados para o social", enquanto Camargo 
mantém-se perplexo ante tal possibilidade. Espero que uma apreensão subliminar ao papel da ética em seus textos, - pela perspectiva do novo pensar filosófico que propomos -, possa ajudar a uma hipótese a este respeito.

Camargo parece relacionar diretamente a Filosofia da Ciência a uma justificativa do predomínio de certa atitude intelectual (qual "colocar as produções da ciências além de qualquer crítica") que pode vir a "sanciona(r) intervenções sociais com base em pressupostos fundamentados pela ciência". Donde define sua posição a partir do entendimento que valoriza a linha de continuidade entre as racionalidades científica e filosófica e a ética (a qual, segundo Atlan, estaria associada à racionalidade mítica), já que, por exemplo, o homossexualismo masculino teria sido discriminado com base em asserções ditas “científicas”. Já Santos, embora contemple os benefícios/malefícios paralelos a tal continuidade (citando Popper), com sutileza e sensibilidade ressalta a importância das "grandes narrativas" (na ordem do mítico, para Atlan), que são "as que agem sobre indivíduos e relações sociais" $e$ "dirigem os fundamentos de nossas experiências" e reconhece a descontinuidade essencial entre as racionalidades quando lembra que se "buscarmos mudanças de atitudes e comportamentos" não há "argumento racional ou evidência" que seja capaz de por si só fazê-lo.

Para Atlan (1994), não há viabilidade de qualquer conclusão científica - por suposição absurda, a realidade biológica das raças humanas (ou seja, a transmissão dos genes em bloco: cor de pele, inteligência, dotes musicais) justificar uma posição ética - o racismo, no caso. À Filosofia da Ciência caberia tão somente apresentar os argumentos (conformes aos padrões mínimos aceitos atualmente como os legítimos à disciplina) que asseveram que nenhuma pesquisa científica é conclusiva (o que nem Sokal \& Bricmont ousariam contestar). O que deve ser privilegiado é o não-convencimento dogmático da prioridade e exclusividade desta ou daquela forma de conhecimento para plena compreensão de qualquer fenômeno em questão (o que não é monopólio, portanto, de nenhuma das racionalidades).

Neste embate Ciências - Ética, a função da Filosofia é a de lembrar a atribuição específica de cada racionalidade, sublinhando-se que a "estrutura epistemológica" da razão mítica nada tem em comum com a da Filosofia da Ciência - ou seja, Ética não é Lógica. Tratar-se-ia, pois, não de "enfraquecer a Forte Ciência" mas sim de "Fortalecer a fraca ética", de modo a equilibrar suas potências na dinâmica intercrí- tica da qual emerge a possibilidade de prática eficiente. Esta diferenciação tem, dentre outros méritos, o do esvaziamento do contraprodutivíssimo equívoco do "politicamente correto", moldado sobre contigüidades conceituais inadequadas. Impele, ao invés, a uma série de comprometimentos íntimos, mas de necessária expressão pública, bem mais complexos (donde de surgimento mais raro) do que as corriqueiras "denúncias" contra os establishments.

A mesma questão é tematizável em termos da delicada indagação de como a transdisciplinaridade se situa em relação à Ética. A meu ver, instala-se aqui, em lugar da continuidade artificial de que falamos acima, uma indiscriminação de fronteiras, que, subentende-se, pela sua intenção de conjugar Bom e Verdadeiro, não poderia senão favorecer as duas tendências as quais D'Ambrosio chama de "pulsões de sobrevivência e transcendência", associando-as ao comportamento e ao conhecimento - no sentido de aumentar suas forças para facultar o aparecimento do que o autor denomina uma “civilização planetária”, moral e culta, humilde, generosa e justa. Concordo com as cuidadosas colocações de Minayo a respeito, que redundam na observação de que, infelizmente para todos nós, não percebemos até hoje "resultados frutíferos" desta proposta; eu aventaria, entretanto, que talvez não se deva "à pequenez de nossa capacidade de aprender e apreender o todo" a razão pela qual não os reconhecemos, ao menos pela perspectiva que a via transdisciplinar tem a oferecer de todo o processo.

Outra vez retomando Atlan (1991), as vias da tentativa de acesso à Virtude - ou à Ética - e à Verdade - ou ao Conhecimento - são absolutamente distintas, uma vez que se estruturam em função de dois tipos de racionalidade, a mítica e a filosófica ou científica (dependendo, aqui, de que concepção de verdade esteja em jogo). Embora o resultado final - sempre relativo a cada momento/situação singular - seja semelhante ao desejado pela transdisciplinaridade (pois em si mesmo corresponderia a um atendimento às várias necessidades do Humano), tal resultado só se exprime na prática, não sendo passível de elaboração abstrata " conjunta”, uma vez que o "todo” não é apreensível, ele só pode ser "vivido" (o que é mais do que “experimentado”). Não se trata, pois, só de diferenças de estratégias ou de metodologias; há uma concepção de base metafísica específica inserida no projeto epistemológico de Henri Atlan - que não cabe aprofundar neste Debate - que deve, entretanto ser citada, pois é o que, a meu ver, dá a dimensão substantiva a seu pensamento. 


\section{Um universal pragmático e o alcance da Filosofia}

Não é possível deixar de me deter um pouco mais no tema do pragmatismo, requestionando os questionamentos de Ayres, este hábil êmulo da astuta, bem humorada "piscadela de olho" atlaniana face às polêmicas. O pragmatismo, após sua fulgurante irrupção no início do século XX, teria começado a perder importância já por volta dos anos 30 e, a seguir, foi, ora confundido com o utilitarismo ou até com o instrumentalismo, ora acusado de auxiliar o "fim da filosofia". Só bem recentemente tem-se revisto esta posição, sob o influxo de filósofos quais Rorty. Este autor, aliás, me merece, também, particular apreço, inclusive porque ouso esboçar certo paralelismo entre ele e Atlan, na medida em que Rorty (1998) propõe, como meta de progresso para a filosofia, o ser mais criativa, desligando-se dos termos, tornados obsoletos e herdados dos grandes filósofos mortos, para pensar a "possibilidade ainda não realiza$d a$ " (Rorty, 1998:25), uma vez que a racionalidade filosófica intermedeia os progressos na ciência e na moral, dos quais se deve dar conta separadamente.

Assim, segundo Rocha (1998:340), pode-se dizer que “(...) quase tudo est(á) por ser feito, se quisermos compreender a intervenção do pragmatista na (...) filosofia". Dentre as várias novas tendências, nem sempre se encontra o citado "horror aos universais". Por exemplo, Dias (1998) discute como o pragmatismo pode estar implicado na adoção de uma perspectiva universalista na moral, esclarecendo que para tal ser implementado - o que teria como conseqüência a criação de regras de conduta diferenciadas - a definição destas mesmas regras só poderia "se dar no âmbito das decisões humanas ou do discurso efetivo, neste sentido só (podendo) ser estabelecidas pragmaticamente" (Dias, 1998:317). Por outro lado, a epígrafe atlaniana de minha resposta a este debate, dirime uma dúvida: o universal pragmático não pode ser $a$ priori, como adequadamente assinala Ayres, e sim, somente a posteriori, já que “(..) $a$ única universalidade de valores possível é aquela que se constrói passo a passo, através da luta, da coexistência e do diálogo. E a única garantia para isso é a boa vontade sem complacência em relação ao outro, ao estranho e ao estrangeiro" (Atlan, 1986:22).

O grifo na citação acima é meu, para registrar a possível recuperação - futura - de dois desafios fascinantes embutidos nas indagações de meu ágil interlocutor: o primeiro sublinha a função da vontade na contextualização das "ex- periências práticas dos sujeitos" que constróem um campo de saber; o segundo, arrisca-se a destrinchar o que seriam "boas" Ciência/ Biologia etc. para Atlan (ou seja, porque ele estaria "agregando" o prescritivo ao assertivo?). Acresço que, efetivamente - como bem o insinua Ayres -, a proposta atlaniana - assim como o projeto de questionamento da transposição "possível/potencial" em curso (ver adiante) - contemplam um universal de interesse emancipatório.

Donde, justamente ao compartilhar a preocupação com a busca de certas universalidades com o prezado debatedor (que, aliás, pareceme reconhecer também em D' Ambrosio e Minayo), lembro ainda que o próprio Rorty (1993) não concorda com o termo "relativista" ser apropriado para o que o filósofo chama "etnocêntrica terceira visão”, esta sim a que deve ser adotada pelo pragmatista.

Talvez, um dos grandes atrativos do pragmatismo seja o seu empenho em "ligar o pensamento à existência, ligar o pensamento à vi$d a$ " (Durkheim, 1955, apud Rocha, 1998:337). Embora procedam as ressalvas de Santos e Barata de que "os grandes filósofos" e "todas as correntes filosóficas pós-kantianas” preocupam-se com a intervenção na realidade concreta, o pragmatismo deixa explícita e decisivamente em segundo plano quaisquer elucubrações da filosofia que não as coincidentes com a prioritária inflexão desta disciplina, ou seja, o oferecimento de hipóteses que "têm valor apenas na medida em que tornam a mente dos homens mais sensível à vida que os cerca" (Dewey, 1946, apud Rorty, 1998:21). Esta "força vitalizante" da filosofia é enfocada por Atlan (1991) nos termos de sua reverberação na experiência democrática. Ele proclama a vocação - a qual transcende sua profissão - do filósofo como a de falar da necessidade humana urgente do aprendizado de uma "arte do pensar" que contribua para uma "arte do viver", de forma a inseminar sua potência junto aos "três poderes da palavra : o político, o científico e o da mídia (poético)" (Atlan, 1991:165).

É em função desta compreensão da responsabilidade do filósofo que discordo do entendimento de Camargo de que não se deva propor algo em troca a Sokal \& Bricmont, uma vez que - injusto e/ou manipulativo que possa ser este inegável fato (no sentido jornalístico e não científico do termo) - sua produção intelectual encontrou entusiástico respaldo junto à mídia. A partir deste momento, não estão mais em jogo prestígios em guerras acadêmicas (e muito menos se os próprios autores estão ou não interessados na réplica) e sim o esclarecimento do público aberto a tal. Se admito (cf. Santos) 
que a mídia não concedeu equivalente espaço para a continuação do debate iniciado por Sokal \& Bricmont, interrogo-me como este teria sido encaminhado pelos acadêmicos ao "público leigo". Compartilho, veementemente, a visão de Domingues de que a riqueza da interação das idéias de forma alguma está restrita às Academias e, pessoalmente, tenho dificuldades em reconhecer como diálogos as justaposições de múltiplas citações pomposas e/ou impactantes, tão apreciadas nestes ambientes. Como Minayo, considero a clareza, a simplicidade e - nas almas mais refinadas - a humildade, os segredos da acessibilidade indispensável ao pensador ativo que acredita que deva participar, criteriosa, atentamente, da assim chamada "formação de opinião".

Cabe ao filósofo - aqui entendido como o detentor, em dada circunstância, da palavra que sirva à vida -, se lhe parecer relevante, explicitar (voltando ao contexto em questão) que, sob a aparente ambigüidade das intenções de Sokal \& Bricmont, reside toda a pujança de convencimento de uma estratégia retórica, que poderia ensaiar caricaturar um tipo de raciocínio filosófico pela negatividade, como o tão magnificamente ilustrado por Bergson e Wittgenstein, por exemplo (para o que Sokal \& Bricmont não demonstram competência, evidentemente). Não esquecendo de mencionar, neste caso, que a retórica, de per si, é inevitável. Ecoando novamente Minayo, “(...) a comunicação científica necessita da retórica para poder circular e repercutir". (É) “(a) medida certa dessa linguagem (que) deve ser uma preocupação de todas as disciplinas". Acrescento que, dado o peso que atribuo ao estilo, reputo a elegância, a ponderação, o senso de proporção - conforme exemplificados em várias corretas críticas ao desabridamento de Sokal \& Bricmont neste debate - a única retórica convincente para lhes fazer face.

Detendo-me, ainda, no tema da comunicação, parece-me extremamente pertinente um dado "ponto de passagem para o desdobramento desta discussão" apresentado por Najar - infelizmente de forma resumidíssima - neste debate: a revolução digital das telecomunicações (etc.) e todas as conseqüências que daí advêm para aumentar o campo de ação da palavra filosófica. Esta tende mais e mais a não precisar se sujeitar (ou não exclusivamente) às formatações a ela impostas pelos oportunismos quer da mídia, quer acadêmicos. Por ser veículo privilegiado à formação de uma "comunidade nômade" (à la Guattari) em processo de expansão em termos de acesso e utilização, o potencial de influência, ainda embrionário, desta notável forma de intercomunicação não deve ser negligenciado.
Enquanto isto, resta-nos a dupla via do rigor e da sensibilidade, como tão bem o sintetizaram vários de nossos interlocutores. Em relação à primeira destas vertentes, aproveito para responder a Ayres e Barata estar o detalhamento das idéias acerca de possibilidade/potencialidade, que foram apenas delineadas neste artigo, inserido dentro de um projeto maior em curso, vinculado à linha de pesquisa acerca do questionamento do modelo de risco, desenvolvida por Luis David Castiel, na Escola Nacional de Saúde Pública. Consoante o princípio de necessária exigência que rege esta equipe de trabalho, tão logo algumas de minhas/nossas conclusões forem consideradas o suficiente elaboradas, serão certamente apresentadas, de maneira, inclusive, mais formal, à comunidade acadêmica.

Mas a segunda das veredas de que falo, a das compartilhadas intuições e esperanças que é também a dos equívocos e implicâncias que, ao se reconhecerem como tais, invertem/têm invertida a sua direção e duplicada sua energia - é a de que se nutre e a que alimenta a rede de interseções significativas a que chamamos Vida do Espírito. É fundamental lembrar que é tão ou mais importante que a anterior e, em consonância com o que é murmurado por Atlan, tem sua própria forma de eficácia, assim como de transmissão, diversas daquelas que são decodificáveis por modelos preestabelecidos, nas Ciências ou nas Humanidades, mas de forma alguma menos atuantes. Foi um prazer e uma honra ter trilhado um trecho deste trajeto em companhia dos participantes deste debate.

ATLAN, H., 1991. Tudo, Não, Talvez, Educação e Verdade. Lisboa: Piaget.

ATLAN, H., 1994. Com Razão ou Sem Ela: Intercrítica da Ciência e do Mito. Lisboa: Piaget.

ATLAN, H., 1999. Les Étincelles de Hasard. Paris: Seuil. ATLAN, H. \& BOUSQUET, C., 1994. Questões sobre a Vida. Lisboa: Piaget.

DIAS, M. C., 1998. Decisionismo e pragmatismo na moral: Sobre a justificativa e implicações na adoção de uma perspectiva universalista. In: Filosofia Analítica, Pragmatismo e Ciência (P. R. M. Pinto, org.), pp. 315-322, Belo Horizonte: Editora da Universidade Federal de Minas Gerais.

DIGGINS, J. P., 1999. Max Weber: A Política e o Espírito da Tragédia. São Paulo: Editora Record.

ROCHA, R. P., 1998. Um espectro ronda a Filosofia. In: Filosofia Analítica, Pragmatismo e Ciência (P. R. M. Pinto, org.), pp. 332-341, Belo Horizonte: Editora da Universidade Federal de Minas Gerais.

RORTY, R., 1993. Solidariedade ou objetividade. Novos Estudos Cebrap, 36:109-121.

RORTY, R., 1998. Pragmatismo, filosofia analítica e ciência. In: Filosofia Analítica, Pragmatismo e Ciência. (P. R. M. Pinto, org.), pp. 15-29, Belo Horizonte: Editora da Universidade Federal de Minas Gerais. 